\title{
Professional Engineers' Needs for Managerial Skills and Expertise
}

This report gives the results of a questionnaire sent to a sample of Chartered Engineers resident in the UK in 2002 to survey what 'managerial' skills and expertise they need in their jobs.

The conclusions are intended to guide employers, teachers, training staff, the professional Institutions, regulatory authorities, government departments and engineers themselves on what may be needed stage by stage in the education and careers of professional engineers.

The report includes comparisons with data obtained in a similar survey in 1979.

A Dudman and S H Wearne

Centre for Research in the Management of Projects University of Manchester Institute of Science \& Technology

March 2003 


\section{OBJECTIVE}

This report gives the data obtained from a questionnaire sent out to samples of Chartered Engineer members of ten Institutions in April-June 2002. The objective has been to provide up-to-date data to guide employers, teachers, training staff, the professional Institutions, regulatory authorities, government departments and engineers themselves on what management skills and expertise may be needed stage by stage in the careers of professional engineers.

A first such survey was run in $1979^{1}$. It was proposed because of lack of agreement between all the interested parties on what management skills and expertise are needed by engineers and how they should obtain them. Agreement on answers to these questions seems to continue to be difficult for two reasons:

- Inadequate information on needs. Reports have stated that engineers feel unprepared for what was described as 'management', but information has been lacking on what they meant by the word and how the needs varied from job to job.

- Inconsistent opinions within industry, for instance that courses cannot turn engineers into managers but that engineers need to be educated on cost control and marketing. These inconsistencies may also be due to the vagueness of the word management.

People initially qualified in engineering are amongst the largest source of the top executives of UK companies $^{2}$, and one survey indicated that more than $50 \%$ of engineers classified themselves as employed in managerial positions. Engineers' managerial skills and expertise are therefore of national importance. Studies in manufacturing in the UK showed that the ability to organise information and communicate was needed by engineers whether formally managers or not. Other stated needs were the ability to supervise and an understanding of industrial relations, but whether because of temperament, education or training, it seemed that some engineers had difficulty in making the transition from the quantitative analysis of physical problems to the qualitative uncertainty of managerial problems. The data to support some of these statements of needs and difficulties was limited, partly subjective and might not be fair comment on engineers educated in more modern courses and good training schemes, but it indicated that preparation for management may be important for many British engineers. On the other hand, questioning of some UK mechanical engineers on their education had showed that they valued their education in "basic principles of engineering" most highly, meaning the technical subjects. Their view was that 'business studies' should be included only if they did not detract from those basics.

The evidence presented to formal inquiries has demonstrated how much policies on the education and training of engineers and managers in this country tend to be influenced by habit and received wisdom. For instance, comments are made that engineering graduates lack practical sense in design or management, compared to their predecessors who were trained by craft apprenticeship and educated part-time or evenings at technical colleges. The very same criticisms were once levelled at those craft-trained predecessors. The lack of reliable information on many such questions may explain why there has been little previous agreement on what are the problems or what should be the remedies.

One trend in degree and continuing education courses for UK engineers over the past 50 years has been to include studies of economics and management subjects. The policies of the Engineering Council and its predecessors have encouraged this ${ }^{3}$, but up-to-date data about the present use or future needs for these subjects or how they vary with age and industry has not been available to guide these policies. Our survey was therefore designed to find our what skills and expertise are needed in tasks related to work planning, costs, markets, organisational relationships, contracts, law, etc. in the work of a sample of professional engineers and to see whether the needs may vary with engineers' ages and between branches of engineering. Comparisons with the data obtained in 1979 also make it possible to see any differences since then. 


\section{THE SCOPE OF THE 2002 SURVEY}

The questionnaire was sent to samples of the members of these ten Institutions:

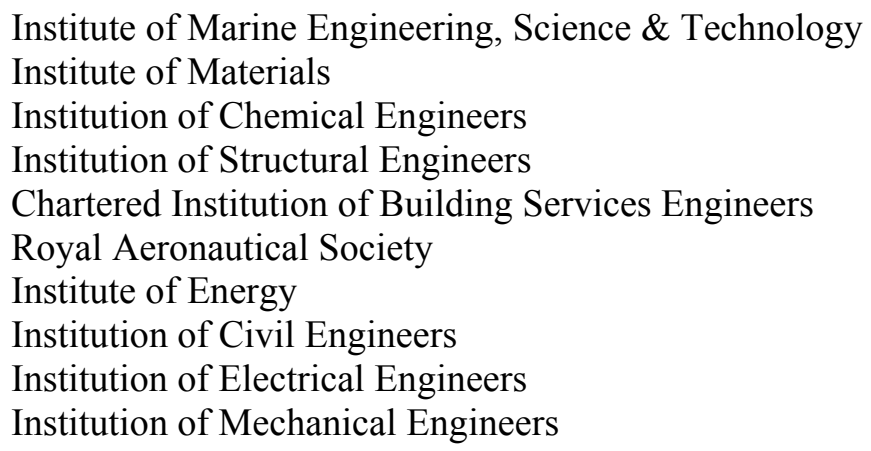

The sample size was planned to be a random selection of at least 1 in 300 of Chartered members resident in the UK and not retired, with a minimum of 10 members per Institution. 1 in 300 had been the sample size in the 1979 survey. It was followed in this 2002 survey on the basis that the research team had the capacity to process answered questionnaires if the response rate was up to $40 \%$.

The questionnaire was posted by the Institutions to the samples of their members, with reply envelopes. The alternative of sending out the questionnaire by email was discussed early in 2002 when planning the work with the Institutions. As a result, half the questionnaire to the Institution of Electrical Engineers members were sent that way, and half by post.

At the suggestion of the Institution of Mechanical Engineers copies of the questionnaire were also sent to a sample of their non-Chartered members for comparisons of data with their Chartered members.

Other Chartered Institutions were not included in this and in the 1979 survey because of their smallness or because managerial qualifications in their industries are controlled under legislation. Some of their members may be included on our sample because of multiple membership. 


\section{THE SCOPE OF THE QUESTIONNAIRE}

The questionnaire requested information from individual engineers on:

- Age and sex.

- Number of years in same job, same organisation.

- Size of organization.

- Qualifications.

- Branch of engineering originally qualified in.

- Job title.

- Technological v. managerial content of job.

- Level of responsibility.

- Number of people responsible to.

- Jobs of people to whom give instructions.

- Number and jobs of people directly responsible for.

- Size of organisations and workplace.

- Extent of autonomy in choosing work objectives.

- Extent of authority in production goals, work schedules.

- Extent that work is co-ordinated by on-the-spot discussion or feedback.

- Extent of freedom to adopt own methods.

- Extent that unexpected problems arise.

- Extent that problems are solved according to known procedures.

- Most difficult or demanding aspect of job

- Detail of managerial skills and expertise required, received in training, required in future - in a table of 47 items or elements of management.

- Whether expecting to change job.

- Type of change expected

- Managerial ambitions. +

- What support expected from Institutions in achieving these ambitions. +

- General comments.

A copy of the questionnaire is attached as Appendix A of this report.

The questionnaire was designed to avoid duplicating the information on the types of jobs, ages, qualifications and salaries of British engineers obtained every year or two by the Institutions, the Engineering Council (UK) and its predecessors.

The questionnaire was based upon one used in the previous surveys since 1979. Following consultations with the Institutions, a few changes made were to revise some of the detailed list of skills and expertise to bring it up to date, and add the two questions marked + above. A question on type of production process that had been included in previous surveys was omitted as it had not yielded useable data. The form and scope of the resulting questionnaire was thus very similar to the one used and pilot-tested for the 1979 survey. Further pilot testing was therefore considered to be unnecessary.

For some Institutions' members a question was added asking whether they would like to take part in follow up discussions of the results of the survey. 


\section{SCALE OF RESPONSE}

227 completed questionnaires were received. The response rate was approximately $30 \%$ of those sent the questionnaire. This is above that achieved by other surveys, but below the $40 \%$ achieved by us in 1979 .

Two factors may have influenced the response rate:

- The selection of samples of Institution members was planned to exclude those retired. Over half the replies from one sample stated that they were in fact retired and returned the questionnaire unanswered as requested in the covering letter. By then spare questionnaires could be sent out to only a few further members of that Institution.

- Not all the samples were sent pre-paid reply envelopes. 


\section{DATA OBTAINED}

This section tabulates the data obtained from the Chartered Engineers who sent in completed questionnaires. Comments on the data follow in Section 6.

The demographic data on the respondents' ages, qualifications, etc. is presented first, followed by the data on their managerial roles and needs. This is different to the sequence of the questions in the questionnaire.

In all the tables the figures in square brackets is the data obtained in the 1979 survey.

Table 1 - Age

$\%$

$\%$

\begin{tabular}{|c|c|c|c|}
\hline Under 30 & $4 \quad[3]$ & \multirow{5}{*}{$\begin{array}{c}\text { All UK } \\
\text { Chartered } \\
\text { Engineers } \\
\text { (not retired) } \\
\text { in } 2001\end{array}$} & 0.9 \\
\hline $30-39$ & $24[33]$ & & 21.2 \\
\hline $40-49$ & 33 [29] & & 34.3 \\
\hline $50-59$ & 33 [28] & & 39.8 \\
\hline $60+$ & $6 \quad[7]$ & & \\
\hline
\end{tabular}

Note: The figures in the right-hand column above for UK Chartered Engineers are based upon the Engineering Council's 2001 survey, the latest with data on ages, but as that data includes retired engineers the percentages have been adjusted on the basis that $94 \%$ of those who would have responded to the questionnaire were under 60 years of age ${ }^{4}$.

Table 2 - Sex

$\%$

$\%$

\begin{tabular}{|c|r|c|c|}
\hline Male & 93.4 & & All UK Chartered Engineers \\
(not retired) in 2002 & 96.4 \\
\hline Female & 4.8 & & 3.6 \\
\hline
\end{tabular}

Table 3 - Number of years in $\begin{array}{llll}\text { present organization } & \% & \text { present job } & \%\end{array}$

\begin{tabular}{|c|c|c|}
\hline Less than one year & $\begin{array}{ll}8 & {[6]}\end{array}$ & $16[12]$ \\
\hline $1-2$ years & 13 [7] & $34[18]$ \\
\hline $3-5$ years & $19[18]$ & $23[30]$ \\
\hline $6-10$ years & $16[17]$ & 12 [17] \\
\hline $11-20$ years & $27[27]$ & 10 [16] \\
\hline $21+$ years & $18[25]$ & $3[6]$ \\
\hline
\end{tabular}

Table 5 - How many people employed at own place of work

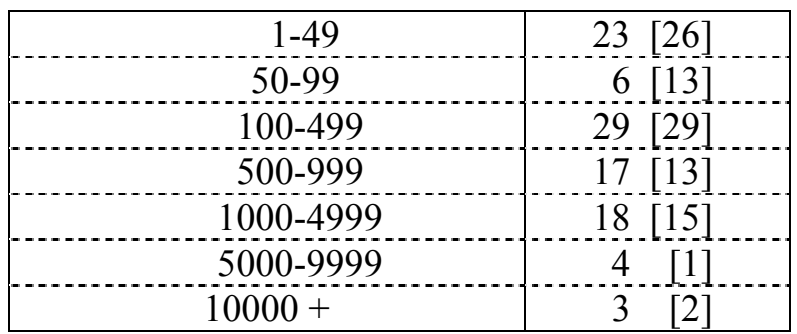

Table 6 - Place of work is one office, one site or department of $\%$ a larger organization ?

\begin{tabular}{|c|c|}
\hline Yes & 76 \\
\hline No * & 23 \\
\hline
\end{tabular}

* i.e. is an independent organization 
Table 7 - Branch of engineering originally qualified in:

\begin{tabular}{|l|r|}
\hline Aeronautical Engineering & 6 \\
\hline Building Engineering & {$[3]$} \\
\hline Civil/Construction Engineering & 18 \\
\hline Chemical Engineering & {$[21]$} \\
\hline Electrical Engineering & 13 \\
\hline Electronic Engineering & {$[15]$} \\
\hline Marine Engineering & 0.4 \\
\hline Materials Science & {$[3]$} \\
\hline Mechanical Engineering & 19 \\
\hline Municipal Engineering & 0 \\
\hline Production Engineering & 3 \\
\hline Structural Engineering & {$[5]$} \\
\hline Engineering Science & 2 \\
\hline General Engineering & {$[0.5]$} \\
\hline Combination of Engineering Subjects & 2 \\
\hline Science Subjects & {$[2]$} \\
\hline OTHERS: Computer Systems Engineering, Geotechnical \\
Engineering, Metallurgy, Gas Engineering, Fuel Technology, \\
Environmental Engineering (2), Solar PV Industry, Manufacturing \\
Systems Engineering
\end{tabular}

Table 8 - Type of qualification

$\%$

\begin{tabular}{|c|c|}
\hline University degree & $69[47]$ \\
\hline CNAA degree & $9 \quad[3]$ \\
\hline Diploma in Technology & 2 [3] \\
\hline Professional Institution examination & $10[20]$ \\
\hline HND & $4 \quad[5]$ \\
\hline $\mathrm{HNC}$ & $1[21]$ \\
\hline NVQ & 1 \\
\hline Other & $4 \quad[1]$ \\
\hline
\end{tabular}

Table 9 - Hold any other higher educational qualification ? \%

\begin{tabular}{l|l} 
Yes & 47 \\
\hline
\end{tabular}

Table 10 - Type of other higher education qualification $\%$

\begin{tabular}{|l|c|}
\hline MBA & 5 \\
\hline Other Management (a) & 6 \\
\hline Teaching qualification & $10.5]$ \\
\hline $\begin{array}{l}\text { Masters degree in Engineering, Technology, Mathematics or } \\
\text { Science }\end{array}$ & $11[2]$ \\
\hline $\begin{array}{l}\text { Postgraduate Diploma / Certificate in Engineering / Technology } / \\
\text { Applied Science }\end{array}$ & 4 \\
\hline PhD, DSc & \\
\hline Other professional (b) & $12]$ \\
\hline
\end{tabular}

Notes: (a) e.g. Diploma in Management Studies, MSc in Business Management

(b) e.g. Accounting, Insurance 
Table 11 - Technological v. managerial content of job

\begin{tabular}{|l|r|}
\hline Predominantly technological & $24[21]$ \\
\hline Predominantly managerial & \\
\hline Both equally & 36 \\
\hline
\end{tabular}

Table 12 - Level of responsibility

$\%$

\begin{tabular}{|l|c|}
\hline Director / Partner & $20[18]$ \\
\hline $\begin{array}{l}\text { Manager / Chief Engineer /Chief Technologist / Principal Engineer } \\
\text { / Principal Technologist }\end{array}$ & $49[41]$ \\
\hline Senior Engineer / Senior Technologist & $19[32]$ \\
\hline Professional Engineer / Professional Technologist & $9[9]$ \\
\hline $\begin{array}{l}\text { Others: } \\
\text { Consultant, Principal, Professional Teacher and Welfare Worker }\end{array}$ & $2[0.2]$ \\
\hline
\end{tabular}

Table 13 - Number of people respondent responsible to $\%$

\begin{tabular}{|c|c|}
\hline 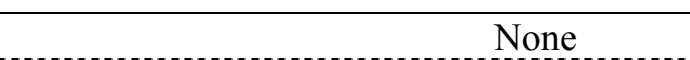 & $13 \quad[8]$ \\
\hline 1 & $48 \quad[64]$ \\
\hline 2 & 17 [18] \\
\hline 3 & $4 \quad[3]$ \\
\hline 4 or more & $12[6]$ \\
\hline
\end{tabular}

Table 14 - Variety of jobs of people responsible to $\%$

\section{Scale *}

\begin{tabular}{|c|c|}
\hline O (Secretarial or ancillary staff only) & \begin{tabular}{lll}
63 & {$[69]$} \\
\hdashline
\end{tabular} \\
\hline 1 (One different level of responsibility or field of expertise) & 19 [16] \\
\hline 2 (Two different levels of responsibility or fields of expertise) & $10[4]$ \\
\hline 3 (Three ditto) & $3 \ldots[2]$ \\
\hline 4 (Four ditto) & $1[0.2]$ \\
\hline 5 (Five ditto) & 0.4 \\
\hline
\end{tabular}

* See also Appendix C

Table 15 - Respondent gives instructions to people not Directly responsible for

\begin{tabular}{|c|c|}
\multicolumn{2}{c}{$\%$} \\
\hline Yes & $74[73]$ \\
\hline No & $25[26]$ \\
\hline
\end{tabular}

Table 16 - Variety of jobs of people to whom respondent gives instructions but for whom not directly responsible

Scale (as above)

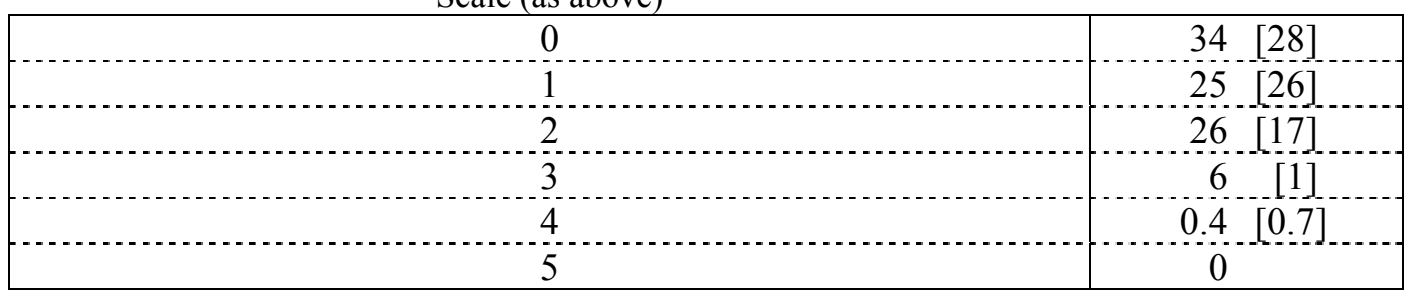


Table 17 - Number of people respondent is directly responsible for $\%$

\begin{tabular}{|c|c|}
\hline None & $30[21]$ \\
\hline 1 & $7 \quad[5]$ \\
\hline $2-3$ & $13[17]$ \\
\hline $4-6$ & $18[26]$ \\
\hline $7-10$ & $13[13]$ \\
\hline $11-20$ & $10 \quad[8]$ \\
\hline $21-50$ & 3 [8] \\
\hline $50+$ & $\begin{array}{ll}4 & {[1]}\end{array}$ \\
\hline
\end{tabular}

Table 18 - Range of jobs of people for whom respondent is directly $\quad \%$ responsible Scale (as above)

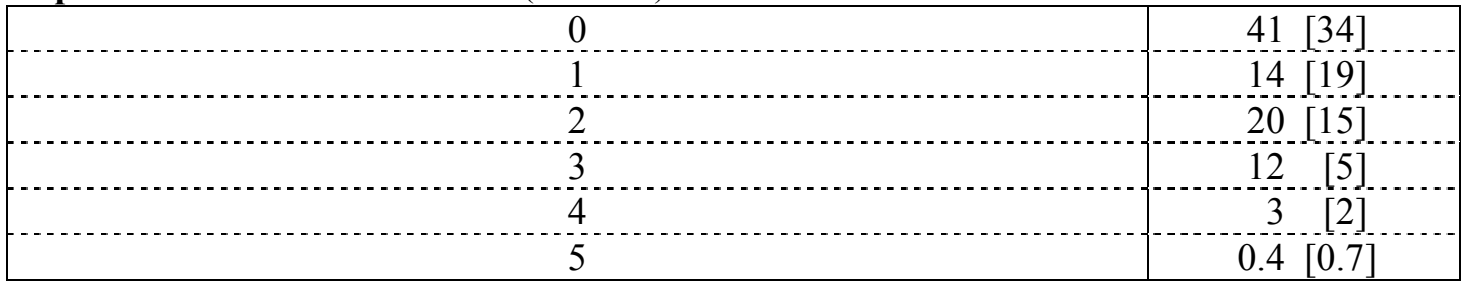

\section{Table 19 - Autonomy, coordination, solution of problems}

Table 19 is a reproduction of the set of pair differential questions included in the questionnaire. The numbers written on to this copy show the percentage distribution of the answers.

\begin{tabular}{|c|c|c|c|c|c|c|c|c|}
\hline $\begin{array}{l}\text { I have a great deal of say in } \\
\text { choosing between different } \\
\text { work objectives to be adopted. }\end{array}$ & $\begin{array}{c}24 \\
{[32]}\end{array}$ & $\begin{array}{c}38 \\
{[34]}\end{array}$ & $\begin{array}{c}17 \\
{[10]}\end{array}$ & $\begin{array}{c}6 \\
{[7]}\end{array}$ & $\begin{array}{c}6 \\
{[6]}\end{array}$ & $\begin{array}{c}7 \\
{[8]}\end{array}$ & $\begin{array}{c}1 \\
{[4]}\end{array}$ & $\begin{array}{l}\text { I have no say. Decisions } \\
\text { about work objectives are } \\
\text { made by someone else. }\end{array}$ \\
\hline $\begin{array}{l}\text { I have a great deal of say in } \\
\text { decisions about production/ } \\
\text { project goals and/or work } \\
\text { schedules.* }^{\text {a }}\end{array}$ & $\begin{array}{l}27 \\
{[29]}\end{array}$ & $\begin{array}{c}34 \\
{[30]}\end{array}$ & $\begin{array}{c}17 \\
{[13]}\end{array}$ & $\begin{array}{c}8 \\
{[6]}\end{array}$ & $\begin{array}{c}4 \\
{[5]}\end{array}$ & $\begin{array}{c}5 \\
{[8]}\end{array}$ & $\begin{array}{c}3 \\
{[8]}\end{array}$ & $\begin{array}{l}\text { I have no say. Decisions } \\
\text { about production/ } \\
\text { project goals and/or } \\
\text { work schedules are made } \\
\text { by someone else.* }\end{array}$ \\
\hline $\begin{array}{l}\text { I co-ordinate the work of others } \\
\text { by on-the-spot discussion } \\
\text { and feedback as it progresses. }\end{array}$ & $\begin{array}{l}12 \\
{[14]}\end{array}$ & $\begin{array}{l}15 \\
{[14]}\end{array}$ & $\begin{array}{c}13 \\
{[11]}\end{array}$ & $\begin{array}{c}20 \\
{[32]}\end{array}$ & $\begin{array}{l}20 \\
{[8]}\end{array}$ & $\begin{array}{l}15 \\
{[11]}\end{array}$ & $\begin{array}{c}2 \\
{[10]}\end{array}$ & $\begin{array}{l}\text { I co-ordinate the work of } \\
\text { others by advance regular } \\
\text { planning and programmes. }\end{array}$ \\
\hline $\begin{array}{l}\text { My own work is co-ordinated by } \\
\text { on-the-spot discussion and } \\
\text { regular feedback as it progresses. }\end{array}$ & $\begin{array}{c}8 \\
{[15]}\end{array}$ & $\begin{array}{c}13 \\
{[15]}\end{array}$ & $\begin{array}{c}13 \\
{[10]}\end{array}$ & $\begin{array}{l}27 \\
{[26]}\end{array}$ & $\begin{array}{c}16 \\
{[12]}\end{array}$ & $\begin{array}{c}14 \\
{[13]}\end{array}$ & $\begin{array}{c}7 \\
{[8]}\end{array}$ & $\begin{array}{l}\text { My own work is co-ordinated } \\
\text { by advance planning and } \\
\text { programmes. }\end{array}$ \\
\hline $\begin{array}{l}\text { I have freedom to adopt my } \\
\text { own methods of work. }\end{array}$ & $\begin{array}{c}38 \\
{[52]}\end{array}$ & $\begin{array}{c}45 \\
{[34]}\end{array}$ & $\begin{array}{r}12 \\
{[8]}\end{array}$ & $\begin{array}{c}4 \\
{[4]}\end{array}$ & $\begin{array}{c}1 \\
{[1]}\end{array}$ & $\begin{array}{c}0.4 \\
{[1]}\end{array}$ & $\begin{array}{c}0 \\
{[1]}\end{array}$ & $\begin{array}{l}\text { The methods of work I } \\
\text { use are decided in detail } \\
\text { by someone else. }\end{array}$ \\
\hline $\begin{array}{l}\text { Unexpected problems rarely } \\
\text { arise in my work }\end{array}$ & $\begin{array}{c}2 \\
{[2]}\end{array}$ & $\begin{array}{c}4 \\
{[5]}\end{array}$ & $\begin{array}{c}8 \\
{[3]}\end{array}$ & $\begin{array}{c}12 \\
{[13]}\end{array}$ & $\begin{array}{c}17 \\
{[11]}\end{array}$ & $\begin{array}{c}32 \\
{[29]}\end{array}$ & $\begin{array}{c}22 \\
{[38]}\end{array}$ & $\begin{array}{l}\text { Unexpected problems } \\
\text { frequently arise in my work. }\end{array}$ \\
\hline $\begin{array}{l}\text { Most problems are solved } \\
\text { according to known procedures }\end{array}$ & $\begin{array}{c}1 \\
{[5]}\end{array}$ & $\begin{array}{c}8 \\
{[14]}\end{array}$ & $\begin{array}{l}15 \\
{[14]}\end{array}$ & $\begin{array}{l}26 \\
{[27]}\end{array}$ & $\begin{array}{l}23 \\
{[18]}\end{array}$ & $\begin{array}{c}19 \\
{[17]}\end{array}$ & $\begin{array}{c}6 \\
{[6]}\end{array}$ & $\begin{array}{l}\text { Most problems require } \\
\text { novel solutions. }\end{array}$ \\
\hline
\end{tabular}

* Note: The word "project" was not included in the above questions in the 1979 survey. 


\section{Table 20 - Most difficult or demanding aspect of job}

The answers to this open-ended question ranged widely, and are of course in each respondent's own words. All their individual statements of what is the most difficult or demanding aspect of their job are listed in Appendix B. For the purpose of analysis these statements have been classified under the following 12 headings:

\begin{tabular}{|c|c|}
\hline & $\%$ \\
\hline None & $1[13]$ \\
\hline Industrial relations & $0 \quad[6]$ \\
\hline People management (a) & $15[14]$ \\
\hline Communications (b) & $3[13]$ \\
\hline Control (c) & $26[7]$ \\
\hline Keeping up with new developments (d) & $5[9]$ \\
\hline Dealing with other senior managers (e) & $7[19]$ \\
\hline Technical (f) & $9[8]$ \\
\hline Business (g) & 14 [11] \\
\hline Political interference, bureaucracy & 1 \\
\hline Risk (h) & 4 \\
\hline Improvements and change (i) & $7[1.9]$ \\
\hline Safety & 0.4 \\
\hline
\end{tabular}

Notes:

(a) including staff recruitment, selection and management, managing a diverse team, motivating others, morale, redundancy, interfacing with out-sourced business, discipline of children in school teaching

(b) including extracting information from colleagues, briefing seniors, assimilating information, writing reports

(c) including targets, budgets, finance, resources, time management, workload, being called out at any hour, balancing competing time demands, travelling and hours worked, having time to do everything, priorities, flexibility, immediacy of decision-making, paperwork, managing service with limited resources, cost control, providing client satisfaction while meeting profit targets, balancing attention to detail against risk of oversight

(d) including new standards, legislation, technical literature

(e) including holding company together, relationships with senior management, getting business to accept need for change, obtaining consensus, not having executive control

(f) including design, innovation, project management, commissioning of new plant, research projects, setting technical standards, moving from technical work to managerial, understanding requirements, design fit for purpose, certification, identifying a new method and getting it implemented, managing new developments, planning new courses, teaching

(g) including strategy, policy development, obtaining work, preparation of bids, contracts, relationships with client, assessing clients' requirements, specifications and changes, insurance, relationships with other consultants, with public and non-technical organizations, intercultural relationships, decision processes in a multi-national

(h) including risk assessment, getting performance to quality standards, problem solving, investigating failures, correcting mistakes made by others.

(i) including variety and wide scope, thinking outside the box and changing mindset, being proactive all the time, coming up with novel solutions, persuading technical managers to improve their skills

Table 21 - Expecting to change job in foreseeable future? \%

\begin{tabular}{|c|c|c|}
\hline & Yes & $41[40]$ \\
No & $58[59]$ \\
\hline
\end{tabular}


Table 22 - Type of job change expected $\%$

\begin{tabular}{|c|c|}
\hline Promotion in same organisation & $13[19]$ \\
\hline A transfer in same organisation & $10 \quad[6]$ \\
\hline A move to another organisation & $11[13]$ \\
\hline A move to self-employment or consultancy & 3 \\
\hline Retirement & $8[8]$ \\
\hline
\end{tabular}

Table 23 - Management ambitions, in terms of responsibilities $\quad \%$

\begin{tabular}{|c|c|}
\hline No further management responsibilities & 8 \\
\hline Develop my present role, self development, recognition & 9 \\
\hline Less responsibility & 2 \\
\hline Greater responsibility, promotion to next level up & 15 \\
\hline Become responsible for multi-disciplinary schemes & 2 \\
\hline Setting policy on standards, etc & 0.4 \\
\hline Manage several projects, manage all work in an area & 11 \\
\hline Senior line management role & 5 \\
\hline Strategic planning & 2 \\
\hline Consultancy, management consultant, adviser, self-employed & 4 \\
\hline Managing Director of own company, strategic management & 2 \\
\hline Voluntary work, hobbies & 0.9 \\
\hline
\end{tabular}

\section{Support expected from the Institute / Institution / Society to assist in achieving management ambitions}

The respondents' answers to the question what support they expected from their Institute / Institution / Society to assist them in achieving their ambitions are listed in Appendix D.

These answers are listed in Appendix D as read from the questionnaires and not in any particular order.

Note: The questions on management ambitions and support expected from Institution were not included in the 1979 survey.

\section{Table 24 - Managerial skills and expertise required in job and in future}

The form of the page of questions on managerial skills and knowledge required and the data obtained from the whole sample of Chartered Engineers are shown overleaf in Table 24.

The numbers written into this copy of the page show the percentage of respondents who said 'Yes' to each topic. Respondents were asked to tick in a column to indicate 'Yes'. No tick meant 'No'.

The first column in the table in the questionnaire offered the alternatives of 'Frequently' or 'Sometimes'. No definition of frequently or sometimes was given by us, as to do so we thought would complicate the questionnaire and deter respondents. In Table 24 the two are shown separately. In later tables these 'Frequently' and 'Sometimes' figures are combined.

The respondents' 'OTHER' entries of skills and expertise added to the table were: Office management; Interpretation of contract conditions; Quality control; Technical auditing; Safety audit/review; Environmental audit; Environmental law; Policy; Teaching; Incident investigation.

Where no figure appears in square brackets the topic was not included in the 1979 survey. 
Table 24 - Detailed 'Management' Skills and Expertise

\begin{tabular}{|c|c|c|c|c|c|}
\hline \multirow[b]{2}{*}{ SKILLS AND EXPERTISE } & \multicolumn{2}{|c|}{$\begin{array}{l}\text { REQUIRED IN } \\
\text { PRESENT JOB }\end{array}$} & \multirow{2}{*}{$\begin{array}{c}\text { INSTRUCTION } \\
\text { RECEIVED IN } \\
\text { BASIC TRAINING }\end{array}$} & \multirow{2}{*}{\begin{tabular}{|c|} 
INSTRUCTION \\
RECEIVED IN \\
SUBSEQUENT \\
TRAINING
\end{tabular}} & \multirow{2}{*}{$\begin{array}{c}\text { ADDITIONAL } \\
\text { REQUIREMENT } \\
\text { IN FUTURE } \\
\text { CAREER }\end{array}$} \\
\hline & Frequently & Sometimes & & & \\
\hline Costing, estimating & $44[33]$ & $45[47]$ & $33[26]$ & $43[32]$ & $16[10]$ \\
\hline Project financing & 26 & 41 & 15 & 39 & 22 \\
\hline Evaluate projects & $47[45]$ & $35[33]$ & $18[16]$ & $40[28]$ & $21[18]$ \\
\hline Analyse project risks & 42 & 39 & 14 & 46 & 19 \\
\hline Analyse corporate risks & 17 & 35 & 5 & 26 & 20 \\
\hline Plan and control budgets & $52[45]$ & $25[21]$ & 19 [10]. & $44[28]$ & 18 [21]. \\
\hline Company accounting & $12[7]$ & $21[14]$ & $12[5]$ & $25[17]$ & $15[14]$ \\
\hline Corporate (business) strategy & 17 & 33 & 4 & 28 & 24 \\
\hline Plan and schedule project & $47[39]$ & 39 [34]. & 30 [17] & $52[28]$ & $16[12]$ \\
\hline Plan new product & $20[11]$ & $26[14]$ & $6 \quad[5]$ & $20[11]$ & $11 \quad[4]$. \\
\hline Patenting & $3[2]$ & $12[11]$ & $2[1]$ & $7[4]$ & $5[1]$ \\
\hline Plan research & $10[7]$ & $18[16]$ & $5[4]$ & $12[6]$ & $4[3]$ \\
\hline Plan design and development & $25[25]$ & $29[22]$ & $20[20]$ & 23 [17] & 111 \\
\hline Plan construction & 18 [20] & $25[23]$ & 16 [18] & 18 [14] & $8[5]$ \\
\hline Plan production & 12 [13] & $10[10]$ & $11[11]$ & 15 [11] & $5[4]$ \\
\hline Plan maintenance & $14[14]$ & $21[20]$ & $11[10]$. & $19[15]$ & $7 \quad[6]$ \\
\hline Plan stocks and materials distribution & $7[10]$ & $9[11]$ & $6[4]$ & $8[11]$ & $2[4]$ \\
\hline Plan services & 14 [14] & $15[17]$ & $6[6]$ & $12[8]$ & 7 [4] \\
\hline Marketing of products & $8[6]$ & $21 \quad[7]$ & $6[1]$ & 19 [10] & $8[7]$ \\
\hline $\begin{array}{l}\text { Marketing of consultancy, technical } \\
\text { services }\end{array}$ & $15[8]$ & $21[12]$ & 4 & $19[6]$ & $12[6]$ \\
\hline Use of company law & $6[3]$ & $30[18]$ & $12[5]$ & $21[12]$ & 19 [12] \\
\hline Use of health \& safety law & 30 [23] & 39 [44] & $23[6]$ & $45[35]$ & 20 [18] \\
\hline Use of employment law & $10[8]$ & $36[25]$ & $10[3]$ & $27[17]$ & $16[15]$ \\
\hline Use of consumer safety law & $4[3]$ & 13 [11] & 3 & $9[6]$ & $8[6]$ \\
\hline Draft contracts & $15[17]$ & $30[27]$ & $12[12]$ & 27 [18] & 17 [12] \\
\hline $\begin{array}{l}\text { Negotia } \\
\text { client/cl }\end{array}$ & $23[18]$ & $34[23]$ & $8[4]$ & $34[13]$ & $19[14]$ \\
\hline supplier/con & $26[28]$ & $37[31]$ & $6[5]$ & 32 [15] & $14[10]$ \\
\hline a employees & $20[17]$ & $27[24]$ & 7 [4] & $30[17]$ & $14[15]$. \\
\hline i T.U. representa & $5[9]$ & 13 [14] & $3[2]$ & 15 [13] & $7[16]$ \\
\hline $\begin{array}{l}\text { Negotiate with public authorities (not } \\
\text { as customers) }\end{array}$ & $11[13]$ & $17[20]$ & $1 \quad[2]$ & $11[7]$ & $6[6]$ \\
\hline Negotiate with senior management & 36 [34] & $33[24]$ & $4[1]$ & 23 [13] & $12[12]$ \\
\hline Statistics & $10[6]$ & $23[31]$ & $25[20]$ & $13[16]$ & $3[6]$ \\
\hline Operational research & $3[3]$ & $9[11]$ & $8[6]$ & $5[9]$ & $3[4]$ \\
\hline Systems analysis & $7[4]$ & $17[18]$ & $8[5]$ & $12[9]$ & $4[6]$ \\
\hline Organisation and Methods (O \& M) & $7[4]$ & $13[17]$ & 9 [7] & 8 [13] & $4[6]$ \\
\hline Work study (methods study) & $3[5]$ & $8[16]$ & $10[12]$ & $8[14]$ & $1[4]$. \\
\hline Data processing & $12[12]$ & $17[28]$ & $14[12]$ & $9[22]$ & $3[12]$ \\
\hline Make formal presentations & 50 & 37 & 27 & 56 & 11 \\
\hline Plan and chair formal meetings & 51 & $34 \ldots .$. & 15 & 43 & 13 \\
\hline Plan personnel requirements & 39 [39] & $26[26]$ & $8[6]$ & $26[16]$ & $14[16]$ \\
\hline Recruit and select personnel & $27[29]$ & $36[36]$ & $7 \quad[6]$ & $35[23]$ & 15 [18] \\
\hline Motivate others & $62[66]$ & $24[15]$ & 13 [8] & $42[30]$ & 13 [15]. \\
\hline Supervise others & $63[67]$ & $25[16]$ & $16[9]$ & $42[30]$ & $14[16]$ \\
\hline Appraise personnel & 44 & 26 & 9 & 50 & 14 \\
\hline Employee training - manual workers & $8[6]$ & 12 [13]. & $2[2]$ & $10[8]$ & $4[6]$ \\
\hline Employee training - supervisors & $8[10]$ & $18[18]$ & $3 .[3]$ & $11[10]$ & $6[7]$ \\
\hline Employee training - management & 13 [11] & $23[17]$ & $4[2]$ & 19 [14] & $11[8]$ \\
\hline OTHERS ............ & $3[7]$ & $2[2]$ & $0[1]$ & $4[4]$ & $0.4[1]$ \\
\hline
\end{tabular}




\section{Skills and Expertise Used at Different Levels of Responsibility and Ages}

Table 25 shows the data on skills and expertise required in their present jobs for the respondents in each of the four levels of responsibility.

Table 26 shows the data on skills and expertise required in their present jobs for the respondents in each age range.

\section{Formal Instruction in Skills and Expertise Required in Present Job}

Table 27 shows the percentage of respondents requiring a skill in their present job for which they had received no instruction. To indicate the relative importance of each item, the first column of data repeats the percentage of respondents stating that they required them in their present jobs.

\section{Data Institution by Institution}

Tables 28 and 29 show the responses on skills and expertise required in their present job from the members of each Institution. Table 28 shows this data for the relatively small number of members of seven of the Institutions. Table 29 shows this data for the members of three Institutions for which comparable data is available from the 1979 survey. Table 29 also shows the data obtained from a sample of members of the Institution of Civil Engineers in 1984 in a repeat of the 1979 survey.

In the report on the 1979 survey the data from the members of the Institution of Chemical Engineers and the Institute of Fuel was combined. To provide a comparison the last column in Table 29 also show the combined data obtained in 2002 from their members.

Comparisons of the data obtained in 1979 and in 2002 are affected by two amalgamations of Institutions. In that time the Institution of Municipal Engineers amalgamated with the Institution of Civil Engineers, and the Institution of Production Engineers amalgamated with the Institution of Electrical Engineers. In Table 29 the data obtained in 1979 from the members of those pairs of Institutions has been combined to provide a basis for comparisons with the 2002 data. 
Table 25 - Skills and Expertise Required by Level of Responsibility

\begin{tabular}{|c|c|c|c|c|}
\hline $\begin{array}{c}\text { SKILLS AND EXPERTISE } \\
\text { REQUIRED IN PRESENT JOB }\end{array}$ & $\begin{array}{c}\text { Professional } \\
\text { Engineer / } \\
\text { Technologist }\end{array}$ & $\begin{array}{c}\text { Senior } \\
\text { Engineer / } \\
\text { Technologist }\end{array}$ & $\begin{array}{c}\text { Manager / } \\
\text { Chief Engr. / } \\
\text { Technologist } \\
\text { Principal / } \\
\text { Engr./Techngst. }\end{array}$ & $\begin{array}{l}\text { Director / } \\
\text { Partner }\end{array}$ \\
\hline Costing, estimating & 95 & 82 & 88 & 93 \\
\hline Project financing & 62 & 55 & 67 & 82 \\
\hline Evaluate projects & 71 & 80 & 81 & 96 \\
\hline Analyse project risks & 71 & 80 & 81 & 96. \\
\hline Analyse corporate risks & 14 & 34 & 53 & 91 \\
\hline Plan and control budgets & 52 & 55 & 85 & 93 \\
\hline Company accounting & 19 & 11 & 26 & 80 \\
\hline Corporate (business) strategy & 14 & 32 & 52 & 84 \\
\hline Plan and schedule project & 86 & 84 & 87 & 89 \\
\hline Plan new product & 43 & 50 & 43 & 56. \\
\hline Patenting & 0 & 21 & 14 & 22 \\
\hline Plan research & 5 & 21 & 33 & 36 \\
\hline Plan design and development & 57 & 57 & 49 & 62 \\
\hline Plan construction & 52 & 34 & 46 & 44 \\
\hline Plan production & 24 & 14 & 23 & 31 \\
\hline Plan maintenance & 48 & 25 & 38 & 36 \\
\hline Plan stocks and materials distribution & 24 & 11 & 14 & 20 \\
\hline Plan services & 43 & 27 & 25 & 40 \\
\hline Marketing of products & 19 & 23 & 23 & 56 \\
\hline $\begin{array}{l}\text { Marketing of consultancy, technical } \\
\text { services }\end{array}$ & 29 & 18 & 32 & 69 \\
\hline Use of company law & 14 & 16 & 33 & 69 \\
\hline Use of health \& safety law & 67 & 57 & 71 & 80. \\
\hline Use of employment law & 19 & 18 & 55 & 62 \\
\hline Use of consumer safety law & 14 & 14 & 13 & 33. \\
\hline Draft contracts & 43 & 30 & 42 & 71 \\
\hline $\begin{array}{l}\text { Negotiate contracts with } \\
\text { client/customer }\end{array}$ & 38 & 41 & 55 & 87 \\
\hline Negotiate with supplier/contractor & 43 & 61 & 62. & 76 \\
\hline Negotiate with employees & 48 & 25 & 52 & 64 \\
\hline Negotiate with T.U. representatives & 5 & 7 & 23 & 24 \\
\hline $\begin{array}{l}\text { Negotiate with public authorities (not } \\
\text { as customers) }\end{array}$ & 19 & 32 & 26 & 31 \\
\hline Negotiate with senior management & 62 & 61 & 74 & 67 \\
\hline Statistics & 29 & 21 & 33 & 44 \\
\hline Operational research & 5 & 9 & 14 & 16 \\
\hline Systems analysis & 10 & 30 & 23 & 29 \\
\hline Organisation and Methods $(\mathrm{O} \& \mathrm{M})$ & 10 & 11 & 23 & 24 \\
\hline Work study (methods study) & 5 & 5 & 10 & 24 \\
\hline Data processing & 24 & 34 & 23 & 38 \\
\hline Make formal presentations & 81 & 80 & 90 & 89 \\
\hline Plan and chair formal meetings & 76 & 71 & 88 & 93 \\
\hline Plan personnel requirements & 52 & 41 & 73 & 80 \\
\hline Recruit and select personnel & 48 & 32 & 75 & 80 \\
\hline Motivate others & 71 & 75 & 92 & 93. \\
\hline Supervise others & 81 & 84 & 89 & 91 \\
\hline Appraise personnel & 62 & 43 & 79 & 80 \\
\hline Employee training - manual workers & 38 & 9 & 23. & 16 \\
\hline Employee training - supervisors & 29 & 11 & 33 & 24 \\
\hline Employee training - management & 29 & 16 & 38 & 60 \\
\hline
\end{tabular}


Table 26 - Skills and Expertise Required by Age Range

\begin{tabular}{|c|c|c|c|c|}
\hline $\begin{array}{c}\text { SKILLS AND EXPERTISE } \\
\text { REQUIRED IN PRESENT JOB }\end{array}$ & $30-39$ & $40-49$ & $50-59$ & $60+$ \\
\hline Costing, estimating & 89 & 93 & 85 & 80 \\
\hline Project financing & 71 & 64 & 67 & 62 \\
\hline Evaluate projects & 87 & 80 & 83 & 85 \\
\hline Analyse project risks & 93 & 79 & 76 & 69 \\
\hline Analyse corporate risks & 44 & 52 & 60 & 54 \\
\hline Plan and control budgets & 69 & 80 & 81 & 62 \\
\hline Company accounting & 33 & 33 & 36 & 39 \\
\hline Corporate (business) strategy & 46 & 59 & 49 & 39 \\
\hline Plan and schedule project & 91 & 89 & 83 & 69 \\
\hline Plan new product & 53 & 49 & 37 & 46 \\
\hline Patenting & 9 & 20 & 13 & 31 \\
\hline Plan research & 24 & 29 & 31 & 31 \\
\hline Plan design and development & 56 & 55 & 47 & 69 \\
\hline Plan construction & 49 & 40 & 41. & 31 \\
\hline Plan production & 29 & 23 & 12 & 46 \\
\hline Plan maintenance & 33 & 33 & 39 & 39 \\
\hline Plan stocks and materials distribution & 20 & 11 & 12 & 31 \\
\hline Plan services & 31 & 35 & 27 & 23 \\
\hline Marketing of products & 27 & 29 & 29 & 39 \\
\hline $\begin{array}{l}\text { Marketing of consultancy, technical } \\
\text { services }\end{array}$ & 29 & 35 & 43 & 54 \\
\hline Use of company law & 35 & 33 & 39 & 46 \\
\hline Use of health \& safety law & 60 & 75 & 69 & 69 \\
\hline Use of employment law & 40 & 52 & 48 & 23 \\
\hline Use of consumer safety law & 11 & 17 & 20 & 31 \\
\hline Draft contracts & 40 & 48 & 47 & 46. \\
\hline $\begin{array}{l}\text { Negotiate contracts with } \\
\text { client/customer }\end{array}$ & 60 & 48 & 68 & 46 \\
\hline Negotiate with supplier/contractor & 67 & 60 & 60 & 54 \\
\hline Negotiate with employees & 53 & 44 & 48 & 31 \\
\hline Negotiate with T.U. representatives & 16 & 15 & 23 & 8 \\
\hline $\begin{array}{l}\text { Negotiate with public authorities (not } \\
\text { as customers) }\end{array}$ & 24 & 24 & 35 & 8 \\
\hline Negotiate with senior management & $7 \overline{5}$ & 65 & 71 & 39 \\
\hline Statistics & 44 & 28 & 27 & 46 \\
\hline Operational research & 16 & 9 & 7 & 39 \\
\hline Systems analysis & 27 & 23 & 15 & 62 \\
\hline Organisation and Methods $(\mathrm{O} \& \mathrm{M})$ & 20 & 15 & 17 & 39 \\
\hline Work study (methods study) & 11. & 9 & 9 & 21 \\
\hline Data processing & 35 & 32 & 19 & 46 \\
\hline Make formal presentations & 84 & 91 & $85^{-}$ & $77^{-}$ \\
\hline Plan and chair formal meetings & 85 & 85 & 88 & 62. \\
\hline Plan personnel requirements & 71 & 69 & 61. & 39 \\
\hline Recruit and select personnel & 60 & 72 & 61 & 54 \\
\hline Motivate others & 93. & 83 & 85. & 77 \\
\hline Supervise others & 95 & 88 & 83 & 69 \\
\hline Appraise personnel & 67 & 77 & 76 & 23 \\
\hline Employee training - manual workers & 27 & 19 & 16 & 15 \\
\hline Employee training - supervisors & 27 & 32 & 21. & 23 \\
\hline Employee training - management & 26 & 41 & 41 & 31 \\
\hline
\end{tabular}


Table 27 - No Formal Instruction in Skills and Expertise Required in Present Job

\begin{tabular}{|c|c|c|}
\hline SKILLS AND EXPERTISE & $\begin{array}{c}\text { Required in their } \\
\text { present job by } \\
\%\end{array}$ & $\begin{array}{l}\text { Percentage of those } \\
\text { requiring each item who } \\
\text { report no instruction in it }\end{array}$ \\
\hline Costing, estimating & 89 & $34[44]$ \\
\hline Project financing & 67 & $37^{-\ldots-1}$ \\
\hline Evaluate projects & 82 & $42[53]$ \\
\hline Analyse project risks & 81 & 36 \\
\hline Analyse corporate risks & 52 & 46 \\
\hline Plan and control budgets & 77 & $34[55]$ \\
\hline Company accounting & 33 & 25 [46] \\
\hline Corporate (business) strategy & 50 & $47[51]$ \\
\hline Plan and schedule project & 86 & 27 [78] \\
\hline Plan new product & 46 & $51[57]$ \\
\hline Patenting & 15 & $68[82]$ \\
\hline Plan research & 28 & 56 [69] \\
\hline Plan design and development & 54 & $42[51]$ \\
\hline Plan construction & 43 & 41 [49] \\
\hline Plan production & 22 & 32 [42] \\
\hline Plan maintenance & 35 & $40[52]$ \\
\hline Plan stocks and materials distribution & 16 & $46[58]$ \\
\hline Plan services & 29 & $49[66]$ \\
\hline Marketing of products & 29 & $41[51]$ \\
\hline $\begin{array}{l}\text { Marketing of consultancy, technical } \\
\text { services }\end{array}$ & 35 & 48 [78] \\
\hline Use of company law & 36 & $35[55]$ \\
\hline Use of health \& safety law & 69 & $25[47]$ \\
\hline Use of employment law & 46 & $33[50]$ \\
\hline Use of consumer safety law & 17 & 49 [67] \\
\hline Draft contracts & 45 & $35[51]$ \\
\hline Negotiate contracts with client/customer & 57 & $39[72]$ \\
\hline Negotiate with supplier/contractor & 63 & 47 [77] \\
\hline Negotiate with employees & 47 & 38 [61] \\
\hline Negotiate with T.U. representatives & 18 & 30 [52] \\
\hline $\begin{array}{l}\text { Negotiate with public authorities (not as } \\
\text { customers) }\end{array}$ & 28 & 57_[78] \\
\hline Negotiate with senior management & 69 & 66 [77] \\
\hline Statistics & 33 & 21 [35] \\
\hline Operational research & 12 & $33[50]$ \\
\hline Systems analysis & 24 & $37[58]$ \\
\hline Organisation and Methods $(\mathrm{O} \& \mathrm{M})$ & 20 & $41[42]$ \\
\hline Work study (methods study) & 11 & 21 [29] \\
\hline Data processing & 29 & 45 [39] \\
\hline Make formal presentations & 87 & 26 \\
\hline Plan and chair formal meetings & 85 & 41 \\
\hline Plan personnel requirements & 65 & $56[74]$ \\
\hline Recruit and select personnel & 63 & 41 [65] \\
\hline Motivate others & 86 & 42 [59] \\
\hline Supervise others & 88 & $44[60]$ \\
\hline Appraise personnel & 70 & 27 \\
\hline Employee training - manual workers & 20 & $49[64]$ \\
\hline Employee training - supervisors & 26 & 54 [66] \\
\hline Employee training - management & 36 & $47[56]$ \\
\hline
\end{tabular}


Table 28 - Skills and Expertise Required in Present Job by Institution Members (see also next page)

\begin{tabular}{|c|c|c|c|c|c|c|c|}
\hline $\begin{array}{l}\text { SKILLS AND EXPERTISE } \\
\text { REQUIRED IN PRESENT JOB }\end{array}$ & IMarEST & IMtls & IChemE & IStructE & CIBSE & $\begin{array}{l}\text { RAero } \\
\text { Soc }\end{array}$ & IEnergy \\
\hline Costing, estimating & 100 & 75 & 100 & 91 & 100 & 92 & 100 \\
\hline Project financing & 33 & 75 & 83 & 64 & 89 & 54 & 67 \\
\hline Evaluate projects & 100 & 63 & 83 & 73 & 100 & 69 & 78 \\
\hline Analyse project risks & 100 & 63 & $92^{\circ}$ & $64^{-}$ & 89 & 77 & 78 \\
\hline Analyse corporate risks & 67 & 50 & 50 & 47 & 67 & 38 & 56 \\
\hline Plan and control budgets & 100 & 50 & $92^{-}$ & 73 & 89 & 77 & 89 \\
\hline Company accounting & 33 & 13 & 33 & 27 & 56 & 8 & 67 \\
\hline Corporate (business) strategy & 33 & 38 & 67 & 18 & 56 & 62 & 56 \\
\hline Plan and schedule project & 100 & 63 & 100 & 82 & 100 & 92 & 89 \\
\hline Plan new product & 33 & 38 & 58 & 27 & 33 & 46 & 44 \\
\hline Patenting & 0 & 38 & 0 & 9 & 0 & 15 & 22 \\
\hline Plan research & 0 & 50 & 17 & 46 & 33 & 15 & 66 \\
\hline Plan design and development & 33 & 25 & 58 & 64 & 67 & 54 & 33 \\
\hline Plan construction & 33 & 25 & $75^{\circ}$ & $55^{-}$ & 67 & 8 & 22 \\
\hline Plan production & 33 & 38 & 42 & 18 & 22 & 15 & 22 \\
\hline Plan maintenance & 33 & 25 & 58 & 18 & 56 & 31 & 33 \\
\hline Plan stocks and materials distribution & 33 & 38 & 25 & 9 & 0 & 15 & 11 \\
\hline Plan services & 67 & 25 & 33 & 18 & 67 & 15 & 44 \\
\hline Marketing of products & 33 & 25 & 42 & 9 & 22 & 23 & 33 \\
\hline $\begin{array}{l}\text { Marketing of consultancy, technical } \\
\text { services }\end{array}$ & 33 & 38 & $42^{-}$ & $46^{-}$ & 56 & 23 & 89 \\
\hline Use of company law & 0 & 25 & 33 & 36 & 11 & 8 & 67 \\
\hline Use of health \& safety law & 33 & 50 & 67 & $55^{-}$ & 78 & 46 & 67 \\
\hline Use of employment law & 0 & 50 & 42 & 27 & 44 & 39 & 56 \\
\hline Use of consumer safety law & 0 & 38 & 17 & 18 & 11 & 8 & 33 \\
\hline Draft contracts & $67^{-}$ & 25 & 67 & 36 & 44 & 39 & 56 \\
\hline $\begin{array}{l}\text { Negotiate contracts with } \\
\text { client/customer }\end{array}$ & 67 & 25 & 83 & $55^{-}$ & 78 & 23 & 67 \\
\hline Negotiate with supplier/contractor & 100 & 50 & 75 & 55 & 78 & 62 & 78 \\
\hline Negotiate with employees & 67 & 38 & 75 & 27 & 44 & 39 & 56 \\
\hline Negotiate with T.U. representatives & 0 & 25 & 33 & 9 & 0 & 8 & 22 \\
\hline $\begin{array}{l}\text { Negotiate with public authorities (not } \\
\text { as customers) }\end{array}$ & 33 & 50 & $42^{-}$ & 36 & 33 & 8 & 22 \\
\hline Negotiate with senior management & 67 & 75 & 83 & 55 & 67 & 77 & 56 \\
\hline Statistics & 33 & 50 & 42 & 9 & 33 & 23 & 78 \\
\hline Operational research & 33 & 38 & 25 & 0 & 11 & 16 & 22 \\
\hline Systems analysis & 33 & 38 & 17 & 9 & 22 & 31 & 33 \\
\hline Organisation and Methods $(\mathrm{O} \& \mathrm{M})$ & 0 & 50 & 33 & 0 & 22 & 8 & 11 \\
\hline Work study (methods study) & 0 & 25 & 17 & 9 & 22 & 16 & 11 \\
\hline Data processing & 0 & 50 & 25 & 27 & 44 & 46 & 44 \\
\hline Make formal presentations & 100 & 75 & $75^{-}$ & $82^{-}$ & 78 & 92 & 100 \\
\hline Plan and chair formal meetings & 100 & 75 & 100 & 64 & 89 & 85 & 78 \\
\hline Plan personnel requirements & 67 & 50 & 75 & 73 & 44 & 62 & 56 \\
\hline Recruit and select personnel & 67 & 63 & 92 & 55 & 33 & 54 & 44 \\
\hline Motivate others & 100 & 100 & 92 & 82 & 78 & 77 & 89 \\
\hline Supervise others & 100 & 75 & 92 & 91 & 78 & 92 & 78 \\
\hline Appraise personnel & 100 & 75 & $92^{\circ}$ & $55^{-}$ & 56 & 69 & 67 \\
\hline Employee training - manual workers & 33 & 50 & 25 & 9 & 0 & 15 & 33 \\
\hline Employee training - supervisors & 0 & 50 & 42 & 18 & 11 & 8 & 44 \\
\hline Employee training - management & 33 & 50 & 58 & 36 & 44 & 39 & 44 \\
\hline
\end{tabular}


Table 29 - Skills and Expertise Required in Present Job by Institution Members (continued)

\begin{tabular}{|c|c|c|c|c|c|}
\hline $\begin{array}{c}\text { SKILLS AND EXPERTISE } \\
\text { REQUIRED IN PRESENT JOB }\end{array}$ & $\begin{array}{c}\text { All CEng } \\
\text { (from Table } \\
24 \text { ) }\end{array}$ & $\begin{array}{c}\text { ICE } \\
{[+ \text { IMunE] }}\end{array}$ & $\begin{array}{c}\text { IEE } \\
{[+ \text { IProdE }]}\end{array}$ & $\begin{array}{l}\text { IMechE } \\
{[\text { CEng] }}\end{array}$ & $\begin{array}{l}\text { IChemE } \\
\text { + IEnergy } \\
\text { [IFuel] }\end{array}$ \\
\hline Costing, estimating & $89[80]$ & $92(87)[88]$ & $84[84]$ & $82[77]$ & $100[78]$ \\
\hline Project financing & 67 & 57 & 64 & 78 & 76 \\
\hline Evaluate projects & $82[78]$ & $78(80)[82]$ & $84[84]$ & 89 [76] & $81[67]$ \\
\hline Analyse project risks & 81 & 78 & 83 & 85 & 86 \\
\hline Analyse coporate risks & 52 & 49 & 55 & 56 & 52 \\
\hline Plan and control budgets & $77[66]$ & 76 (72) $[66]$ & $73[75]$ & $78[66]$ & $91[67]$ \\
\hline Company accounting & $33[21]$ & $32(24)[14]$ & $35[27]$ & $44[27]$ & $48[20]$ \\
\hline Corporate (business) strategy & 50 & 49 & 52 & 63 & 62 \\
\hline Plan and schedule project & $86[73]$ & $81(74)[71]$ & $88[80]$ & $78[76]$ & $95[67]$ \\
\hline Plan new product & $46[25]$ & $22(14)[9]$ & 68 [33] & $26[34]$ & $52[17]$ \\
\hline Patenting & $15[13]$ & 5 (4) $[2]$ & $23[18]$ & $7[21]$ & $10[17]$ \\
\hline Plan research & $28[23]$ & $16(20)[20]$ & $25[21]$ & $22[26]$ & $38[25]$ \\
\hline Plan design and development & $54[47]$ & $49(46)[43]$ & $55[44]$ & $48[59]$ & $48[42]$ \\
\hline Plan construction & $43[45]$ & $62(58)[59]$ & $38[40]$ & $33[35]$ & $52[30]$ \\
\hline Plan production & $22[23]$ & $11(13)[6]$ & 22 [29] & 30 [29] & 33 [28] \\
\hline Plan maintenance & $35[34]$ & $35(27)[20]$ & $31[40]$ & $44[35]$ & $48[39]$ \\
\hline Plan stocks and materials distribution & $16[21]$ & $5(16)[15]$ & 16 [25] & $22[24]$ & 19 [20] \\
\hline Plan services & 29 [31] & $11(22)[19]$ & 29 [37] & 37 [35] & 38 [25] \\
\hline Marketing of products & $29[13]$ & $22(8)[2]$ & $31[17]$ & $37[18]$ & $38[14]$ \\
\hline $\begin{array}{l}\text { Marketing of consultancy, technical } \\
\text { services }\end{array}$ & $36[20]$ & 41 (27)[17] & $27[16]$. & $37[22]$ & $62[34]$ \\
\hline Use of company law & $36[21]$ & $38(20)[17]$ & $43[28]$ & $41[20]$ & $48[20]$ \\
\hline Use of health \& safety law & 69 [67] & $84(54)[67]$ & 69 [69] & 78 [71] & 67 [58] \\
\hline Use of employment law & $46[33]$ & $57(29)[32]$ & 43 [34] & 59 [35] & 48 [33] \\
\hline Use of consumer safety law & $17[14]$ & $0 \quad(6)[2]$ & $23[22]$ & $15[13]$ & $24[17]$ \\
\hline Draft contracts & $45[44]$ & $54(62)[62]$ & $40[41]$ & $52[37]$ & $62[28]$ \\
\hline $\begin{array}{l}\text { Negotiate contracts with } \\
\text { client/customer }\end{array}$ & $57[41]$ & $68(49)[40]$ & 55 [39]. & 63 [41] & $76[39]$ \\
\hline Negotiate with supplier/contractor & $63[59]$ & $76(60)[60]$ & $60[57]$ & $48[62]$ & $76[50]$ \\
\hline Negotiate with employees & $47[41]$ & $57(38)[39]$ & $40[40]$ & $56[45]$ & $67[50]$ \\
\hline Negotiate with T.U. representatives & $18[23]$ & $19(15)[17]$ & $13[26]$ & $26[25]$ & $29[33]$ \\
\hline $\begin{array}{l}\text { Negotiate with public authorities (not } \\
\text { as customers) }\end{array}$ & $28[33]$ & $60(46)[59]$ & $18[25]$ & $4[22]$ & $33[28]$ \\
\hline Negotiate with senior management & 69 [58] & $81(46)[55]$ & $61[57]$ & $67[63]$ & 71 [67] \\
\hline Statistics & 33 [37] & $27(27)[31]$ & 35 [44] & $26[38]$ & $57[22]$ \\
\hline Operational research & $12[14]$ & $0(7)[11]$ & $12[13]$ & $15[14]$ & $24[11]$ \\
\hline Systems analysis & $24[22]$ & $11(13)[17]$ & 34 [29] & $15[20]$ & $24[8]$ \\
\hline Organisation and Methods (O \& M) & $20[21]$ & $16(14)[22]$ & $20[22]$ & $22[22]$ & $24 \quad[6]$ \\
\hline Work study (methods study) & $11[21]$ & 0 (14) $[18]$ & $10[22]$ & $15[25]$ & 14 [11] \\
\hline Data processing & $29[40]$ & $22(44)[42]$ & 33 [45] & $15[35]$ & $33[36]$ \\
\hline Make formal presentations & 87 & 81 & 84 & 93 & 100 \\
\hline Plan and chair formal meetings & 85 & 97 & 83 & 82 & 91 \\
\hline Plan personnel requirements & $65[65]$ & $70(63)[61]$ & $61[87]$ & $67[73]$ & $67[56]$ \\
\hline Recruit and select personnel & $63[65]$ & $70(60)[59]$ & $64[75]$ & $67[64]$ & $71[69]$ \\
\hline Motivate others & 86 [81] & 89 (79) [77] & $86[85]$ & $89[85]$ & $91[72]$ \\
\hline Supervise others & $88[83]$ & $95(88)[84]$ & $84[80]$ & $85[84]$ & $86[89]$ \\
\hline Appraise personnel & 70 & 78 & 64 & 74 & 81 \\
\hline Employee training - manual workers & $20[19]$ & $16(15)[14]$ & $20[16]$ & $22[18]$ & $29[33]$ \\
\hline Employee training - supervisors & $26[28]$ & $30(26)[22]$ & $21[36]$ & $30[28]$ & 43 [31] \\
\hline Employee training - management & $36[28]$ & $43(26)[26]$ & $30[29]$ & $30[28]$ & $52[17]$ \\
\hline
\end{tabular}

Note: The figures in round brackets are the results obtained from ICE members in $1984 .^{6}$ 
Final questions:

Table 30 - Would like a copy of the report on this survey ? \%

\begin{tabular}{|l|l|} 
Yes & $56[54]$ \\
\hline
\end{tabular}

Table 31 - Would like to take part in follow up discussions of $\quad \%$ the results of the survey? *

\begin{tabular}{|l|l|} 
Yes & 41 \\
\hline
\end{tabular}

* The percentage shown is the response of the members of the Institute of Materials, Institution of Civil Engineers, Institution of Mechanical Engineers, Royal Aeronautical Society and Institute of Energy whose questionnaires included this question.

\section{Respondents' General Comments}

The final page of the questionnaire invited respondents to add any general comments. Their responses to this invitation are listed in Appendix E.

These comments are listed in Appendix E as read from the questionnaires and not in any particular order. 


\section{VALIDITY OF THE DATA OBTAINED}

\section{The Respondents}

The distributions of the respondents by age and by sex shown in Tables 1 and 2 correspond to the data on Chartered Engineers from the recent surveys by the Engineering Council (UK). That our 2002 respondents are older than those questioned in 1979 accords with the report by the Engineering Council (UK) of the change in the age profiles of Chartered Engineers in 2001 compared to 1988. Also consistent with this is our data that a greater proportion of the 2002 respondents state that they are in the higher levels of responsibility compared with those in 1979.

The data on the respondents' autonomy and authority in their present jobs shown in Table 19 is consistent with data obtained by the Engineering Council (UK), as discussed in the next section.

No other data on UK engineers is known to be available for comparison with the data obtained from our questionnaire.

Half of the sample of the Institution of Electrical Engineer's members were sent the questionnaire by post, and half by email. Appendix G shows that there were some differences between the two in their qualifications, ages, levels of responsibilities and technological $v$ managerial content of jobs, and the respondents sampled by email were rather younger than is typical of that Institution's Chartered Engineer membership as a whole. ${ }^{*}$

\section{Answers to the Questions}

The few interviews conducted when pilot testing the questionnaire in 1979 indicated that those respondents had had little difficulty in understanding the questionnaire and that we could make valid interpretations of their answers to it.

Some of the answers to the questionnaire as used in 2002 indicate that two questions in it may have been unsatisfactory:

- Negotiations with senior management - Table 24 shows that $67 \%$ of the respondents who classified themselves as in the top level of responsibility also stated that they needed skill etc. in negotiating with 'senior management'. They presumable meant negotiating amongst their fellow top managers. By 'senior' we meant superiors in a hierarchy. The responses to this question are therefore dubious.

- To how many people are you directly responsible ? - Some respondents answered the question "To how many ..." with the same detail as they answered the question "For how many ...". We have not included the answers which seemed clearly addressed to the latter question. Others may have read the question the same way, so the net results shown in Table 13 remain dubious.

Inspection of the other answers obtained in 2002 shows no overall bias of characteristics which would suggest that it is unrepresentative of the population of Chartered Engineers. As in any voluntary survey, the questionnaire was more likely to be answered by those with an interest in the subject and actions on it. Engineers whose jobs were predominantly managerial might therefore be unduly represented in the data. But so might engineers who, as quoted earlier, value their education in "basic principles of engineering" and wish to balance the current view that courses should be broader. Other than the respondents' possible interests in responding to the survey we therefore have no reason to doubt that the answers obtained are representative.

\footnotetext{
* Organisers of surveys should therefore note that the make-up of the respondents answering by post and by email was different and that there were differences between their answers to the questionnaire.
} 


\section{COMMENTS ON THE DATA OBTAINED}

\section{Present Jobs - Authority and Autonomy - Table 19}

The respondents' answers shown in Table 19 show that they are highly autonomous in choosing their work objectives, decisions about schedules and adopting methods of work. These are characteristics of a profession. This data is consistent with the answers to the question "Which of the following best describes the extent your work is supervised ?" obtained in the 2002 Engineering Council (UK) survey of Registered Engineers and reproduced in a table in Appendix $\mathrm{H}$ at the end of this report.

The data in Table 19 shows the extent of our respondents' authority and responsibilities for supervision. Their answers correspond with the answers to the question "Which of the following best describes the extent of your present authority ?" obtained in the 2002 Engineering Council (UK) survey of Registered Engineers also reproduced in Appendix H.

The data in Table 19 also shows that unexpected problems are dominant, and that many require novel solutions. This combined with great autonomy indicates that many engineers need to be quite selfsufficient in understanding the business implications of their decisions and to be equipped with the management techniques to implement these decisions effectively.

\section{Present Jobs - Most Difficult or Demanding Aspect - Table 20}

The respondents' statements reproduced in Appendix B range very widely. They are best appreciated from the respondents' own words, but even from the summary of the answers in Table 20 it is evident that control, people-related and business problems dominate the answers and that most of their jobs at all levels of responsibility demand personal and organizational skills and expertise. The statements shown in Appendix B thus provide a basis for defining actions to improve management systems and to plan training and continuing education programmes.

Comparisons with the data obtained in 1979 follow later.

\section{Managerial Skills and Expertise Required in Present Job - Table 24}

The data in the first two columns in Table 24 shows that every one of the 47 management skills and expertise listed in the questionnaire were stated as required in their present jobs by at least $10 \%$ of this sample of Chartered Engineers as a whole. Some were required by up to $88 \%$ of them.

The following were required by at least $75 \%$ of all the respondents:

- Costing, estimating

- Supervise others

- Make formal presentations

- Motivate others

- Plan and schedule project

- Plan and chair formal meetings

- Evaluate projects

- Analyse project risks

- Plan and control budgets

Table 24 shows that the following were required by at least $50 \%$ of all the respondents:

- Project financing

- Analyse corporate risks

- Corporate (business) strategy

- Plan design and development 
- Use of health \& safety law

- Negotiate contracts with client/customer

- Negotiate with supplier/contractor

- Negotiate with senior management

- Plan personnel requirements

- Recruit and select personnel

- Appraise personnel

The following were required by less than $25 \%$ of the respondents:

- Work study (methods study)

- Operational research

- Plan stocks and material distribution

- Patenting

- Negotiate with T.U. representatives

- Use of consumer safety law

- Employee training - manual workers

- Organisation and Methods (O \& M)

- Plan production

- Systems analysis

The prominence of the project-related as well as people-related topics is consistent with choices made by engineers and others when choosing between options in continuing education courses, and also the answers obtained in an early survey of chemical engineers.

\section{Comparisons between Levels of Responsibility, Ages and Institutions}

To provide a basis for comparing the skills and expertise required in the respondents' present jobs at different levels of responsibility, ages and Institutions, we have grouped the 47 items in Table 24 into 9 groups, as shown in the following Table 32.

The grouping of the 47 skills and expertise into these 9 groups is based upon factor analysis of the data obtained in 1979 , with the additional items added where most closely related.

The right-hand column in Table 32 shows the percentages of the average requirement of the set of managerial skills and expertise included in each of the 9 groups, calculated from the detail in Table 24. The effect of grouping the 47 items is to reduce the range of the data, but the resulting range nevertheless varies from $21 \%$ to $86 \%$. In Table 32 the groups are placed in descending order of average requirement group by group.

Following this, Figure 1 displays the relative importance of the 9 groups of skills and expertise in the respondents' present jobs. It illustrates the dominance of the Projects and Leadership groups of requirements.

A series of such figures is then used to see how the requirements vary between different levels of responsibility, ages and Institutions. 
Table 32 - Management Skills and Expertise Groups

\begin{tabular}{|c|c|c|}
\hline $\begin{array}{l}\text { GROUP OF } \\
\text { SKILLS AND } \\
\text { EXPERTISE }\end{array}$ & $\begin{array}{l}\text { DETAILED SKILLS AND EXPERTISE } \\
\text { INCLUDED }\end{array}$ & $\begin{array}{c}\text { REQUIRED IN } \\
\text { PRESENT JOB } \\
\text { GROUP AVERAGE } \\
\% \\
\end{array}$ \\
\hline \multirow[t]{4}{*}{ LEADERSHIP } & Make formal presentations & \multirow[t]{4}{*}{86} \\
\hline & Plan and chair formal meetings & \\
\hline & Motivate others & \\
\hline & Supervise others & \\
\hline \multirow[t]{4}{*}{ PROJECTS } & Costing, estimating & \multirow[t]{4}{*}{82} \\
\hline & Evaluate projects & \\
\hline & Analyse project risks & \\
\hline & Plan and schedule project & \\
\hline \multirow[t]{6}{*}{ BUSINESS } & Project financing & \multirow[t]{6}{*}{53} \\
\hline & Analyse corporate risks & \\
\hline & Plan and control budgets & \\
\hline & Company accounting & \\
\hline & Corporate (business) strategy. & \\
\hline & Use of company law & \\
\hline \multirow[t]{6}{*}{ PERSONNEL } & Use of employment law & \multirow[t]{6}{*}{51} \\
\hline & Negotiate with employees & \\
\hline & Negotiate with T.U. representatives & \\
\hline & Plan personnel requirements & \\
\hline & Recruit and select personnel & \\
\hline & Appraise personnel & \\
\hline \multirow[t]{5}{*}{ COMMERCIAL } & Marketing of products & \multirow[t]{5}{*}{46} \\
\hline & Marketing of consultancy, technical services & \\
\hline & Draft contracts & \\
\hline & Negotiate contracts with client/customer & \\
\hline & Negotiate with supplier/contractor & \\
\hline \multirow[t]{4}{*}{$R \& D$} & Plan new product & \multirow[t]{4}{*}{36} \\
\hline & Patenting & \\
\hline & Plan research & \\
\hline & Plan design and development & \\
\hline \multirow[t]{8}{*}{ OPERATIONS } & Plan construction & \multirow[t]{8}{*}{32} \\
\hline & Plan production & \\
\hline & Plan maintenance & \\
\hline & Plan stocks and materials distribution & \\
\hline & Plan services & \\
\hline & Use of health \& safety law & \\
\hline & Use of consumer safety law & \\
\hline & Negotiate with public authorities (not as customers) & \\
\hline \multirow[t]{3}{*}{ TRAINING } & Employee training - manual workers & \multirow[t]{3}{*}{27} \\
\hline & Employee training - supervisors & \\
\hline & Employee training - management & \\
\hline \multirow[t]{6}{*}{ TECHNIQUES } & Statistics & \multirow[t]{6}{*}{21} \\
\hline & Operational research & \\
\hline & Systems analysis & \\
\hline & Organisation and Methods $(\mathrm{O} \& \mathrm{M})$ & \\
\hline & Work study (methods study) & \\
\hline & Data processing & \\
\hline
\end{tabular}




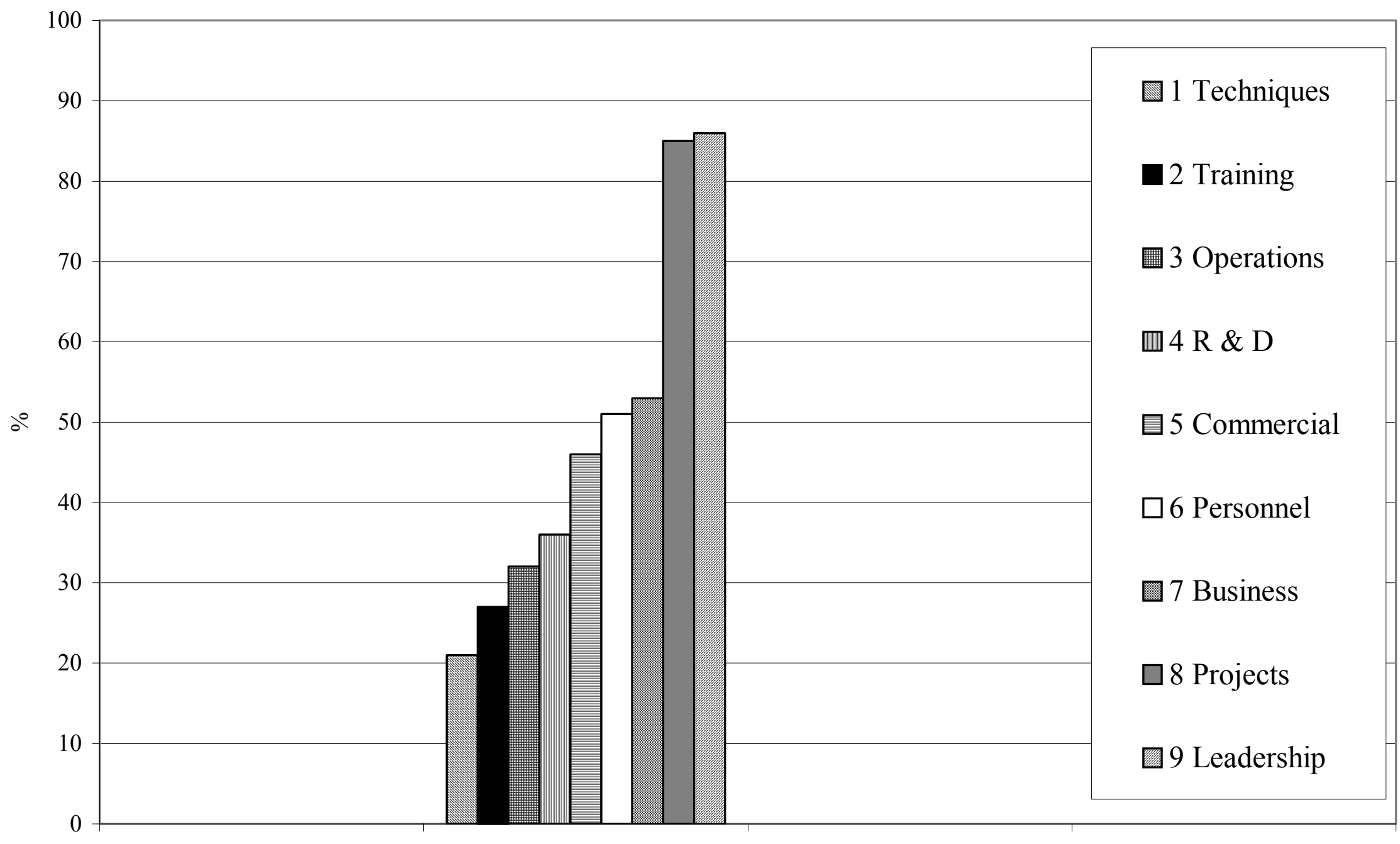

Figure 1 - Groups of Skills and Expertise Required by Chartered Engineers in Present Jobs Members of 10 Institutions 


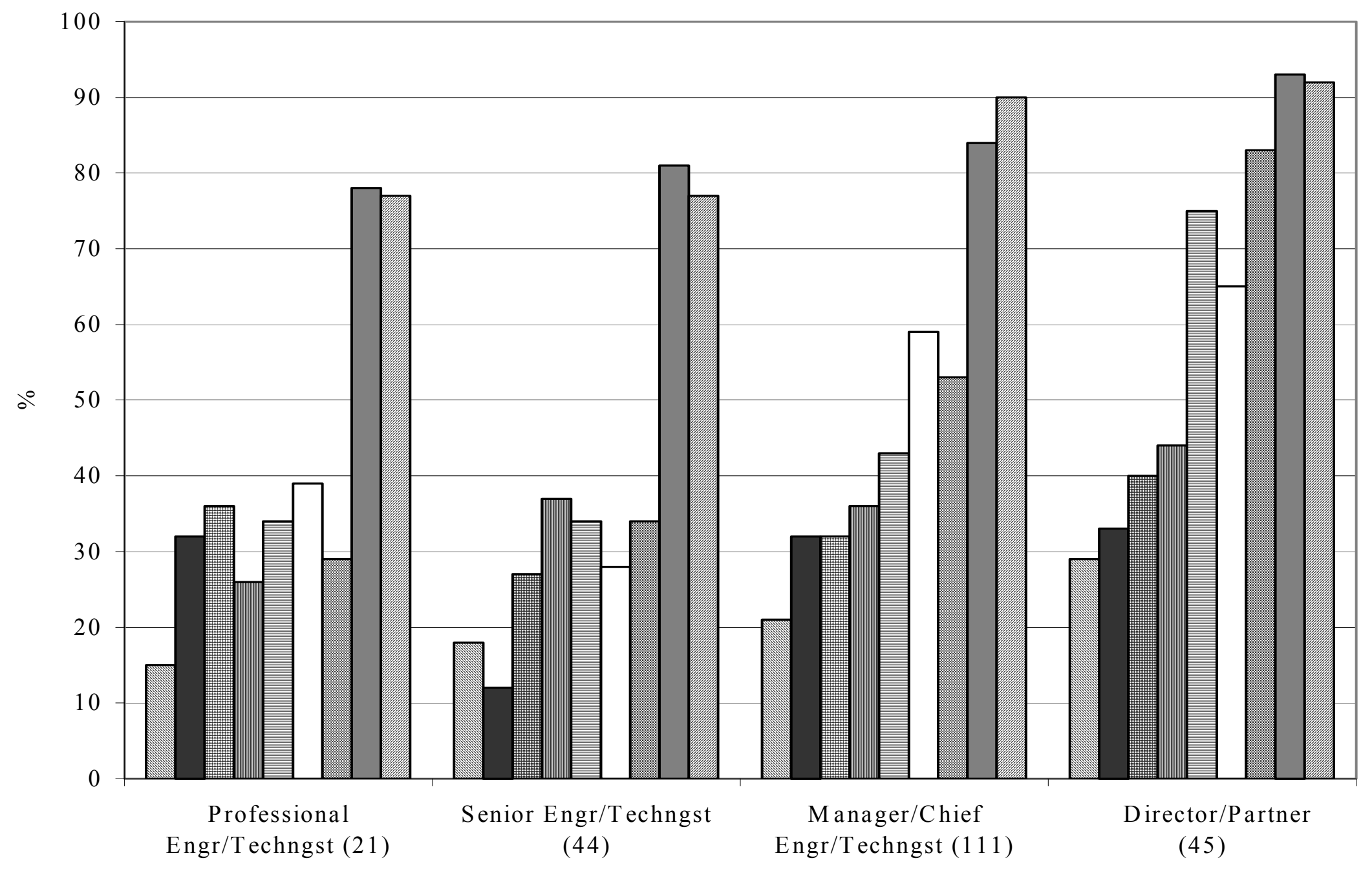

$\square 1$ Techniques

$\square 2$ Training

$\square 3$ Operations

$\square 4 \mathrm{R} \& \mathrm{D}$

$\square 5$ Commercial

$\square 6$ Personnel

$\square 7$ Business

$\square 8$ Projects

$\square 9$ Leadership

Figure 2 - Groups of Skills \& Expertise Required compared with Level of Responsibility 


\section{Skills and Expertise Required by Level of Responsibility - Figure 2}

Differences in the requirements for the 9 groups of managerial skills and expertise at different levels of responsibility are illustrated in Figure 2. This summarises the detailed differences to be seen in the data shown in Table 25.

Figure 2 shows that the greater requirements for managerial skills and expertise are at the higher levels of responsibility, as expected, but that the requirements do not increase uniformly level by level. Across all four levels the Projects and Leadership groups remain dominant, but the Professional Engineer/Technologist level have a greater requirement for the Training, Operations and Personnel skills and expertise than do the Senior level.

\section{Skills and Expertise Required by Age Range - Figure 3}

Differences in the requirements for the 9 groups of managerial skills and expertise at different ages are illustrated in Figure 3. This summarises the detailed differences to be seen in the data shown in Table 26.

Figure 3 shows that the requirements for managerial skills and expertise do not necessarily increase with age. The requirements for the dominant Leadership and Projects groups decrease a little from age to age, and the decrease in the Leadership group amongst the 60+ respondents is accompanied by a decrease in their requirement for Personnel skills and expertise. These respondents show the highest use of Techniques, particularly compared with the respondents in the middle age ranges.

These results of requirements by age compared with those in the previous figure suggest that the respondents tend to be at the peak of level of responsibility is between 40 and 59 . We therefore analysed these two variables. The results are shown in Table 33. They confirm that the peak level of responsibility was typically around age 50 rather than later.

Though they overall required less, Figure 3 shows that the $60+$ respondents required the most even mix of the 9 groups of skills and expertise. We thought that this and their relatively low requirements for the Personnel and the Leadership skills and expertise may be due to more of them being selfemployed than are the other respondents. The questionnaire did not ask directly whether respondents were self-employed, but this may be inferred from the answers given to the questions on how many people they are responsible to and for. Table 33 shows that the $60+$ age group reported the lowest levels of responsibility to others and for others. This is consistent with their being more selfemployed than are the respondents in the other age groups.

Table 33

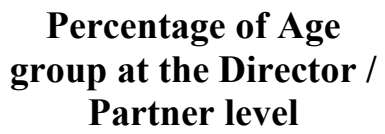

Age Group
Percentage of Age group not responsible to others
Percentage of Age group not responsible for others

\begin{tabular}{|c|c|c|c|}
\hline lage & & & \\
\hline 30-39 & 11 & 11 & 32 \\
\hline $40-49$ & 31 & 10 & 21 \\
\hline $50-59$ & 42 & 19 & 31 \\
\hline $60+$ & 16 & 30 & 73 \\
\hline
\end{tabular}

Roles as consultants and having to be managerially more self-sufficient may explain why the $60+$ age group have the highest requirements for the Techniques group of skills and expertise. 


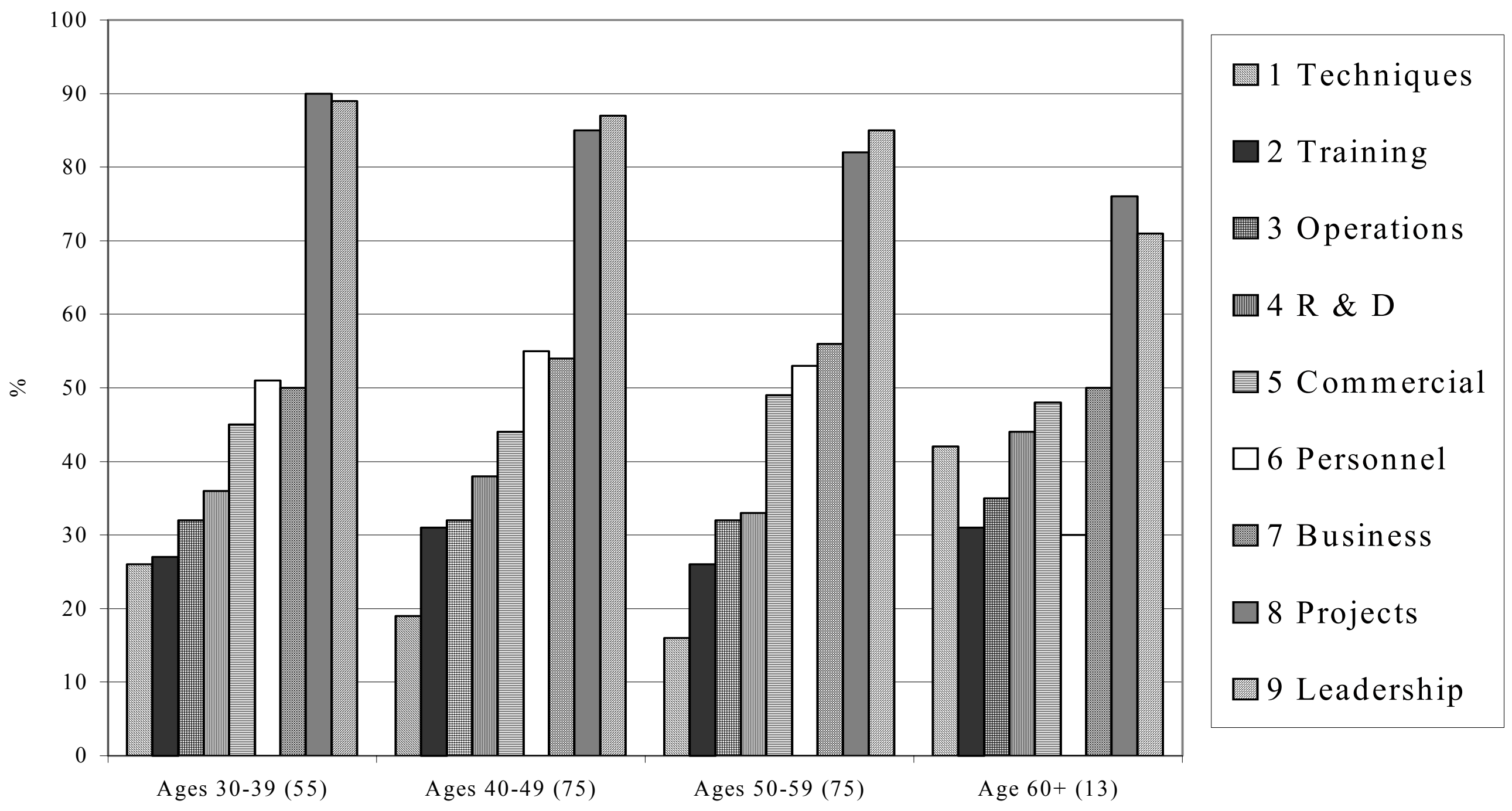

Figure 3 - Groups of Skills \& Expertise Required compared with Age 


\section{Differences between Skills and Expertise Required by Institution Samples - Figures 4 to 6}

Differences in the requirements for the 9 groups of managerial skills and expertise required by the respondents from each of the Institutions are illustrated in Figures 4, 5 and 6. These tables summarise the detailed differences to be seen in the data shown in Tables 28 and 29. The data from all the Institutions is displayed though the samples are small in order to get at least an indication of differences in the relative use of managerial skills and expertise.

Figures 4 to 6 show that the respondents of all ten Institutions are similar in most requiring the Leadership and Projects groups of skills and expertise in their present jobs, though with differences in extent, and some differences between all of them in the relative need for the 9 groups of skills and expertise.

Within each of the 9 groups of topics there are also significant but predictable differences to be seen in the data in Tables 28 and 29. For instance, though in Figure 5 the Institution of Mechanical Engineers and Institution of Civil Engineers respondents are shown to have similar requirements for the Operations group skills and expertise, Table 29 shows that the former have the greater involvement in planning production, and the latter in planning construction. Both of these require similar skills and expertise, so that Figure 5 may correctly show the relative importance of the Operations group of topics, but their application varies from one type of work to another. 


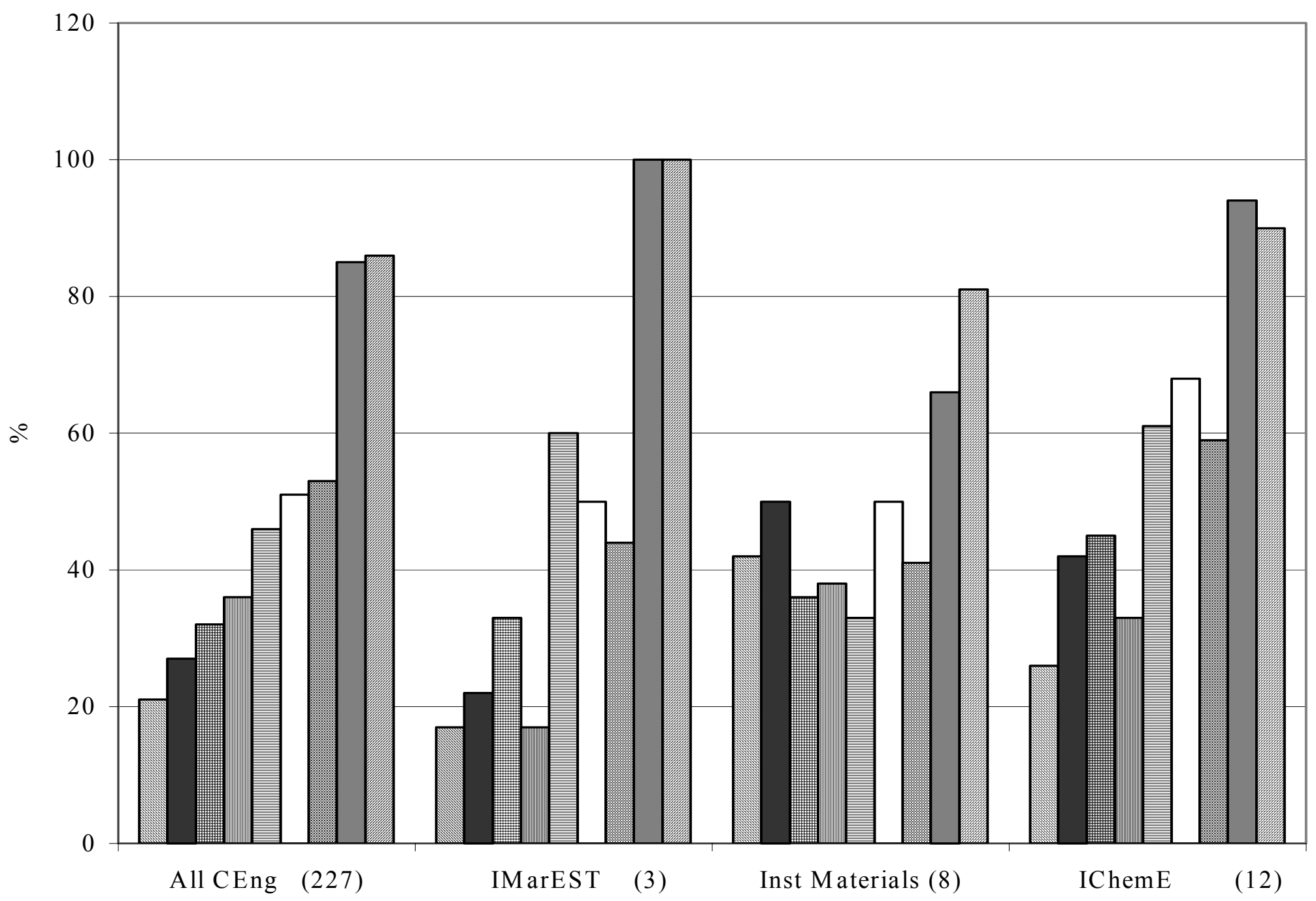

1 Techniques

$\square 2$ Training

$\square 3$ Operations

$\square 4 \mathrm{R} \& \mathrm{D}$

$\square$ 5 Commercial

$\square 6$ Personnel

$\square 7$ Business

$\square 8$ Projects

$\square 9$ Leadership

Figure 4 - Use of Groups of Skills \& Expertise by Institution Members I 


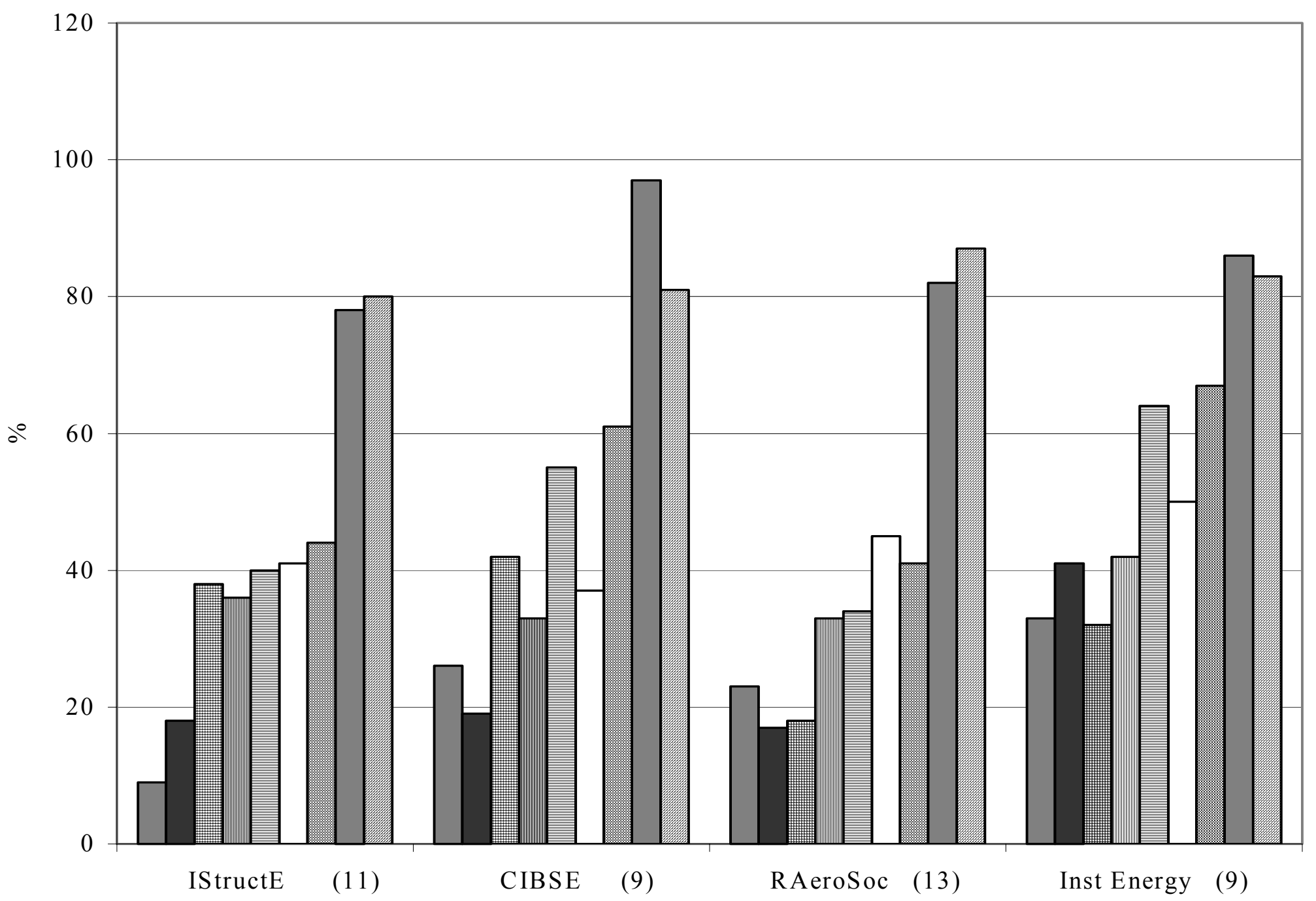

$\square 1$ Techniques

$\square 2$ Training

$\square 3$ Operations

$\square 4 \mathrm{R} \& \mathrm{D}$

吕 Commercial

$\square 6$ Personnel

$\square 7$ Business

$\square 8$ Projects

$\square 9$ Leadership

Figure 5 - Use of Groups of Skills \& Expertise by Institution Samples - II 


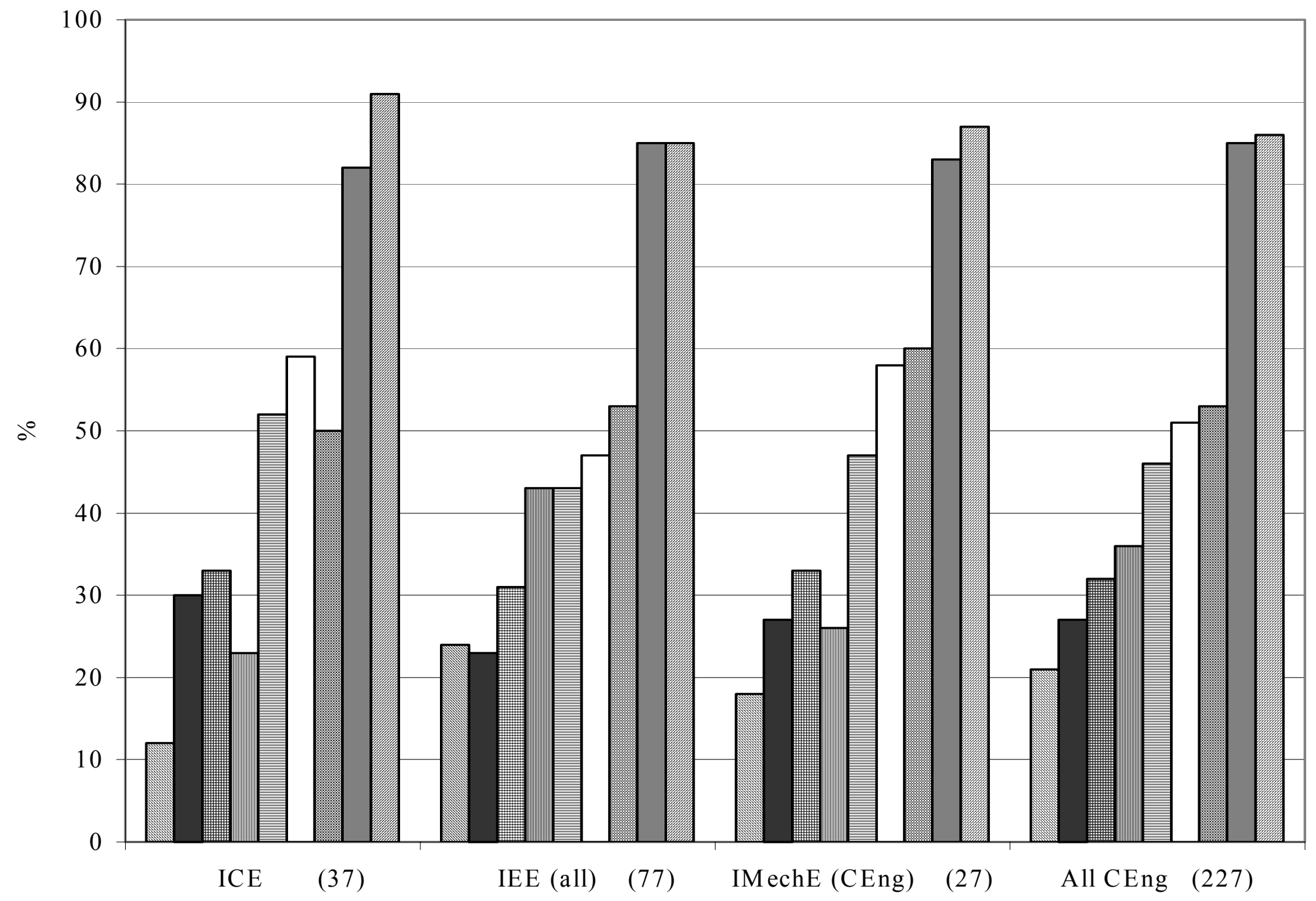

$\square 1$ Techniques

$\square 2$ Training

$\square 3$ Operations

$\square 4$ R \& D

邑5 Commercial

$\square 6$ Personnel

7 Business

$\square 8$ Projects

9 Leadership

Figure 6 - Use of Groups of Skills \& Expertise by Institution Samples - III 


\section{Changes Compared with the 1979 Data}

As expected, Table 8 shows an increase in the proportion of respondents with university degrees and a great increase in the proportion of respondents with higher degrees, including MBA's.

The 2002 data in Table 5 on how many people employed at place of work shows little change since 1979. The downsizing policies of companies might have shown in changes in that data, but we have not found data on the scale of downsizing in UK business or public services to see whether it might have affected engineering employment over this time. If a continuing trend, downsizing would be expected to increase the importance of buying and selling compared to organizational skills and expertise. An investigation of the trends and effects of downsizing on the content of jobs could be of value to all concerned with the training of engineers.

The 2002 data in Table 21 on whether expecting a job change also shows little change since 1979, yet what is commonly thought to be greater uncertainty today in business and public employment might have caused differences in the answers to the answers to this question. Though only of note in this survey, this is also an issue for investigation.

Compared with 1979, Table 20 shows a marked decrease in the proportion of respondents who did not report anything as the most difficult or demanding aspect of their present job. Financial and other pressures may have increased the difficulties and demands, and perhaps engineers in 2002 were more willing to be specific. The difficulties and demands categorised as 'Control' are mentioned much more in the 2002 answers than in 1979. The detailed statements reproduced in Appendix B indicate that control of costs is a major cause of difficulties and demands. This seems logical given the increasing pressures of competition in business and public services. Perhaps the lower reporting in the 'Communications' category is due to improvements from more use of IT effectively.

The decrease in stating "Dealing with other senior managers" as the most difficult or demanding aspect of job may be misleading because of doubts about the interpretation of 'senior managers'.

The ranking of the 47 items of skill and expertise in the first column in Table 24 as stated by the respondents in 2002 is very similar to 1979 , but there is an increase in their requirements for skills and expertise in:

- Costing, estimating

- Company accounting

- Plan new product

- Marketing of products

- Marketing of consultancy, technical services

- Use of company law

- Use of employment law

- Negotiate contracts with client/customer

- Negotiate with senior management

There is a decrease in:

- Plan stocks and material distribution

- Negotiate with T.U. representatives

- Negotiate with public authorities (not as customers)

- Statistics

- Work study (methods study)

- Data processing

but in any case none of the latter are greatly used items. 


\section{Preparation Received for Managerial Tasks - Table 27}

The data in the second column of Table 27 indicates that many of the respondents to the 2002 questionnaire had not received any training in some important managerial items. Compared to 1979, instruction in many of them has increased, but is still lacking in the heavily used Leadership, Personnel and Project skills, and in most others. Surprisingly, a large number report no instruction in Data processing.

\section{Instruction Received in Subsequent Training - Table 24}

The fourth column of data in Table 24 shows that the respondents report considerable increase in instruction received in subsequent training, compared to the 1979 respondents, except in a few items that are those less required in their present jobs. That the respondents report an increase in instruction received in subsequent training is what we would expect given the development of requirements for Chartered Engineers to follow CPD programmes.

In answering that part of the questionnaire the respondents were not saying that they had obtained all the instruction they needed for the rest of their careers. Their statements listed in Appendix B can be taken to mean that many need better instruction, guidance and support in their managerial tasks. Evidence that instruction received is inadequate (or ineffective) in managerial skills such as communications is also to be found in another review of statements by engineers and others in industry questioned on what are the greatest problems in project management ${ }^{7}$.

\section{Requirements in Future Careers - Table 24}

The data in the last column in Table 24 indicates that respondents considered that they would require most of the skills and expertise for their future careers, and in particular:

- Corporate (business) strategy

- Project financing

- Evaluate projects

- Analyse corporate risks

- Costing, estimating

- Use of health \& safety law

- Analyse project risks

- Use of company law

- Negotiate contracts with client / customer

- Plan and control budgets

- Costing, estimating

and the need for these has on balance increased since the 1979 survey.

\section{Support Expected to Assist in Achieving Management Ambitions - Appendix D}

Respondents stated in their own words their answers to the question what support they expected from their Institute / Institution / Society to assist them in achieving their ambitions. All are listed in Appendix D. They vary widely. They are not readily classifiable, but the following are the most common categories:

- Continuing professional development, including for senior colleagues

- Career advice

- Meetings

- Networking

- Library and journals, including job opportunities

- Standards and best practices 
- Help for small and medium size enterprises (SME's)

- Promoting the role and recognition of engineers

- Business Centre services

- Professional indemnity insurance

It was helpful to this survey that respondents who stated that they expected little or no support from their Institution to assist in achieving their managerial ambitions were nevertheless willing to answer the questionnaire.

\section{Respondents' General Comments - Appendix E}

The general comments given by some respondents were also of course stated in their own words. The comments vary widely. They provide comments on maintaining Institution standards, problems of management, careers and employment, engineers in management and issues also mentioned in the statements about support from the Institutions. Some were comments on the questionnaire and the answers given to it.

\section{Non-Chartered Members - Appendix F}

At the suggestion of the Institution of Mechanical Engineers the questionnaire was also sent to a random sample of 1 in 300 of their non-Chartered members.

Tables in Appendix F show the data from the non-Chartered and the Chartered members of that Institution. There were some differences between the two in their qualifications, ages, levels of responsibility and technological $\mathrm{v}$ managerial content of jobs, as would be expected. Table F1 in Appendix F shows that the Chartered members had the greater needs for some managerial skills and expertise, particularly in: Company accounting; Corporate (business) strategy; Company law; Employment law; Negotiating contracts with client/customers; and Data processing. The nonChartered members had the greater needs in: Planning new products, research, design and development, and construction; Patenting; and Negotiating with public authorities (not as customers). Both groups had similar high needs for the Personnel-related skills.

\section{Postal and Emailed Responses to the Questionnaire - Appendix G}

Half of the sample of the Institution of Electrical Engineer's members were sent the questionnaire by post, and half by email.

Tables in Appendix G show data from these two half samples of members of that Institution. There were some differences between the two in their qualifications, ages, levels of responsibilities and technological v managerial content of jobs. For instance, the respondents sampled by post were at more senior levels and older. Interestingly more of them reported technical issues as the most difficult or demanding aspect of their job. The email respondents reported people management as the most difficult or demanding aspect of their job.

Appendix G shows the age distribution of these two sets of respondents and of the whole Chartered membership of their Institution. Our sample has a higher proportion aged 30-39, and a lower proportion aged $60+$. This first difference appears to be in those who answered by email. The second difference may be because members do not necessarily notify the Institution that they are retired. Members who were sent the questionnaire but were retired were asked not to answer the questionnaire, so there should be none amongst the respondents to the survey, whereas the Institution totals may include members who are retired. The age distribution of the two half samples combined are closer than is either half sample to the age distribution of the whole Institution. We have therefore used their combined data in the main body of this report, but the result may be that their younger members are over-represented in the data. 


\section{CONCLUSIONS}

The purpose of these surveys has been to obtain quantitative evidence to help provide a basis for reviewing and planning the education and continuing development of professional engineers.

Many of the results are no surprise. They accord with common sense. Comparison with the data from the previous surveys was not the objective, but the differences are what might be expected from known trends. The similarity of the data obtained from the small sample of engineers questioned in 2002 compared with 1979 also suggests that valid information was obtained.

The data shows that most engineers' careers include managerial tasks though many remain in predominantly technological jobs. A quarter of the respondents described their jobs as predominantly technological but over $80 \%$ indicated that they needed some of the 'managerial' skills and expertise listed in Table 24. The people-related answers to the question what is the most difficult or demanding aspect of job outweighed the technologically-related answers. For engineers generally, managerial and social skills and expertise may therefore be as important as technical ones, and not least for newly Chartered Engineers. The respondents to the 2002 questionnaire reported a considerable increase in instruction received in subsequent training, compared to the 1979 survey, but they also clearly indicated their wish for more preparation for their future managerial tasks.

It does not follow that engineering students should study management equally with technology. One obvious reason is that some managerial tasks are not encountered until later in a career. The problems may have changed by the time today's students reach the higher levels of responsibility. On the other hand, what is not studied as a student may never be learnt at all, or not learnt at all thoroughly. The increase in 2002 in the proportion of respondents with higher degrees in management subjects indicates that some engineers and employers recognise the need for more professional preparation. This is consistent with the trend for studies to precede experience that is characteristic of the evolution of all professional work.

These surveys were not intended to define a standard scheme of management studies for engineering students and the stages in their careers. The data obtained indicates that the needs vary between the members of the Institutions. We would expect that a survey which questioned a larger sample might well also show differences between different careers within each sector of employment. In any case, variety can be argued as the right pattern in all education policies, to avoid all being wrong, as well as to meet different interests and careers.

Various objectives can be important in planning engineering courses. One argument is that subjects such as economics can have value in educating engineers as citizens, whatever utility they may have vocationally. Also it can be argued that Britain's dependence upon invisible exporting requires the maximum internal investment in education and that for engineers management skills and expertise have higher added-value than more technological ones. That is not to say that academic studies can be a substitute for experience. What can be achieved is a disciplined basis for learning from experience better and faster. Including "management" in engineering courses may also attract good students and help them to obtain jobs. These arguments may explain the current view that engineering courses should be broader. But we have to note that there has been much opinion but little evidence to support or to contradict any of these views. The preference of some of industry's middle and junior managers may be to recruit engineering graduates who have immediately useful knowledge. Employability and then success in the first years of an engineer's career may thus depend upon competence in technical matters combined with communications and managerial skills.

The respondents' statements of the most difficult and demanding aspect of their jobs are an indicator of actions needed by them and their employers. Many of these are probably well known to employers and their advisers and accepted as needing action. Corporate systems also need to be seen to learn. The respondents to this survey stated what they saw as the difficulties and demands. Statements of current problems do not necessarily represent future needs, and the needs as seen by employees do not necessarily correspond with what their employers recognize as important for their business ${ }^{8}$. But 
the engineers questioned were at all levels in their organizations. They do or they direct the work which influences the success of their employers. If what they have said is right, corporate actions are needed to reduce the costs of the problems. If what they say is wrong, corporate systems need to learn why they are wrong. Actions which don't appear to address the problems as seen by the people influential on the quality, safety, delivery and cost of products, processes and services may fail to be supported by them.

The surveys have concentrated on the managerial needs of engineers' jobs. The data obtained has indicated that engineers need considerable expertise in some 'managerial' tasks early in their careers even when not in predominantly management jobs, but there is a lack of comparable surveys of the technological content of their jobs to provide a balanced basis for discussing possible changes to courses, training and career development policies. Our samples of the membership of each Institution were also relatively small, and are only another 'snapshot' of jobs at the time. More extensive and regular surveys are needed covering all the work and future needs of engineers at stages in their careers.

\section{REFERENCES}

1 Faulkner, A C, \& Wearne, S H (1979). Professional Engineers' Needs for Managerial Skills and Expertise, report TMR 15A, School of Technological Management, University of Bradford.

2 Engineering Council (UK) (2001). Engineers for Britain - Digest of Statistics.

3 Starting with The Engineer in Society syllabus, the Council of Engineering Institutions, 1966, and now embodied in The Educational Basis for Chartered Engineers, SARTOR, $3^{\text {rd }}$ edition, 1997, the Engineering Council.

4 Engineering Council (UK), 2001 Survey of Registered Engineers.

5 Engineering Council (UK), 2002 Survey of Registered Engineers.

6 Faulkner, A C, \& Wearne, S H (1984). Civil Engineers' Needs in Construction Managerial, report TMR 153, School of Technological Management, University of Bradford.

7 Hussain, R \& Wearne, S H. Problems of Project Management 1991 - 2002, report in preparation, Centre for Research in the Management of Projects, University of Manchester. Institute of Science \& Technology.

8 Morris P W G (1998). Why project management doesn't always make business sense, Project Management, v 4, n 1, pp 12-16.

\section{BIBLIOGRAPHY}

Edgeworth-Johnstone R (1969). Continuing education in engineering with special reference to chemical engineers, The Chemical Engineer, supplement.

EMTA (2002). 2002 Labour Market Survey of the Engineering Industry in Britain, Training Publications Ltd.

EMTA (2001). 2001 People Skills Scoreboard, Training Publications Ltd.

Engineering Council (UK) (2000), Standards for Professional Engineers - A Guide for Employers [summary of SARTOR, $3^{\text {rd }}$ edition, 1997] 
Engineering Management Partnership, www.emp.ac.uk

Faulkner A C \& Wearne S H (1980). Professional engineers' needs for managerial skills and expertise, Technical Note, Proceedings of the Institution of Civil Engineers, Part 1, v 68, pp103-104.

Faulkner A C \& Wearne S H (1984). Managerial Skills and Expertise used by Samples of Engineers in Britain, Australia, Western Canada, Japan, the Netherlands and Norway, report TMR 152, School of Technological Management, University of Bradford.

Finnegan R E, Wearne S H, \& de la Mare R F (1987). Managerial Needs of Chartered Builders, report of survey, TMR 154, School of Technological Management, University of Bradford.

Finnegan R E, Wearne S H \& de la Mare R F (1987). Managerial Needs of Architects, report of survey, TMR 155, School of Technological Management, University of Bradford.

Finniston Committee (1979). Engineering our Future, Report of the Committee of Enquiry into the Engineering Profession, chairman Sir Monty Finniston .

Mason, G (1999). The Labour Market for Engineering, Science and IT Graduates: Are There Mismatches between Supply and Demand?, DfEE Research report 112, National Institute for Economic and Social Research.

Ramsay, A (1999). Chartered and incorporated engineers - a comparison, Civil Engineering, Proceedings of the Institution of Civil Engineers, May /August 1999, pp 66-67.

Ramsay, A (2002). Route master, Professional Engineering, 27 November, pp 28-29.

Roberts, G (2002). SET for Success: the Supply of People with Science, Technology, Engineering and Mathematics Skills, H M Treasury.

Wearne S H (1985), Development of project engineers, International Journal of Project Management, v 3, n 3, August, pp 150-152. 
Dear Member

April 2002

\section{THE MANAGERIAL CONTENT OF ENGINEERS’ JOBS}

We should be very grateful if you would help us by giving some information for a survey of the 'managerial' knowledge and skills used by Chartered Engineers. Samples of the membership of other engineering Institutions are being asked to give the same information. The purpose is to provide data to guide policies as to how much expertise in finance, planning, negotiating, industrial organisation, the law, etc, if any, should be included in engineering courses or at various stages of a career in engineering. A similar survey was carried out in 1979, so we shall also be able to see any changes in needs since then.

We therefore ask you to complete the attached questionnaire and return it in the enclosed addressed envelope. Replies will be strictly confidential. Our analysis and conclusions will be circulated to the Institutions, the new Engineering \& Technology Board, the Engineering Council (UK), committees and others concerned with engineering and management education.

Please answer the questionnaire in terms of your present work. For our results to be representative, it is important to have replies from people in all sorts of engineering jobs, regardless of 'managerial' content. The variety of work which people trained in engineering go on to do is obviously very wide, so if some of the questions do not appear to be directly relevant to your present work, please answer as best you can. The extent to which engineers not working in industry may have managerial responsibilities is relevant to this enquiry, so if, for example, you are a teacher, please complete the questionnaire.

If you are retired, unemployed, or the questionnaire as a whole is inapplicable to you for another reason, please return it unanswered with a note of the reason.

Many of the spaces for your answers include code numbers for our use in analysing the information. Please ignore these numbers. Please tick the appropriate box corresponding to your answer, or write an answer in where this is indicated.

We shall be most grateful for your help.

Yours truly 
In order to be able to contrast skills in different branches of engineering some information on your education is requested:

Q. 1 (a) What is the major subject of your basic educational qualification in engineering

(Please tick one box)

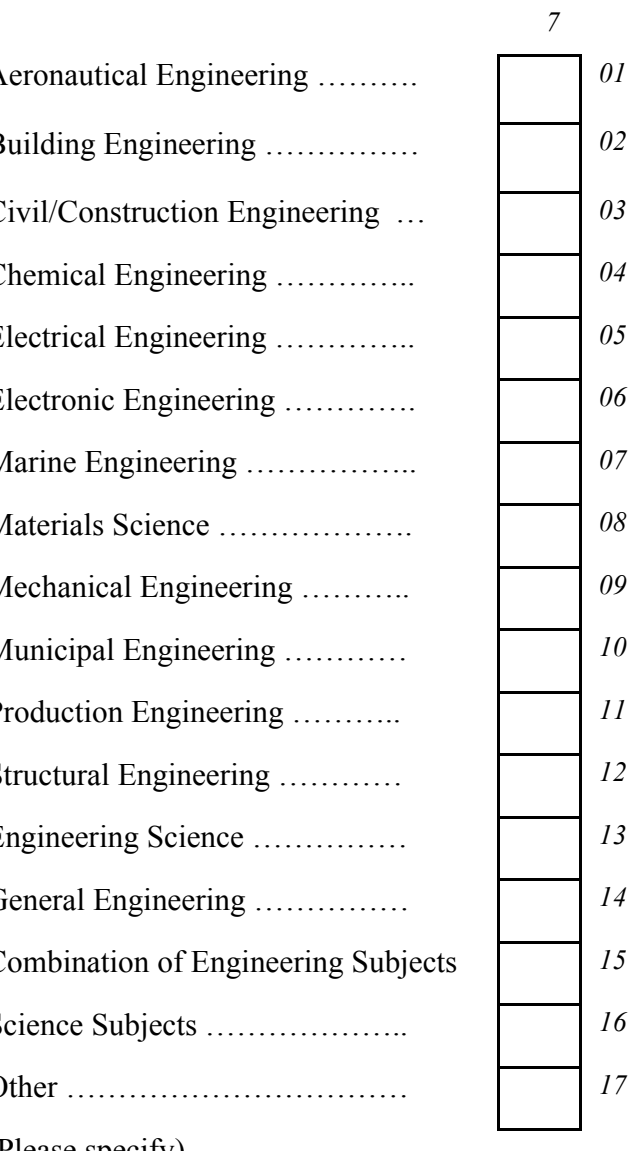

(b) Which of the following is your

University degree highest level of qualification CNAA degree in this subject? Diploma in Technology

(Please tick one box)

Professional Institution examination

HND

$\mathrm{HNC}$

NVQ at Level .... (Please enter)

Other

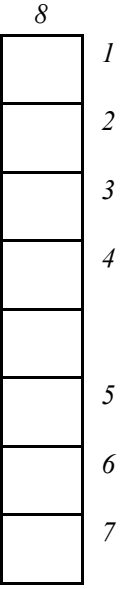

(c) In which year did you attain this qualification? (Please write in)

(d) Do you hold any other higher educational

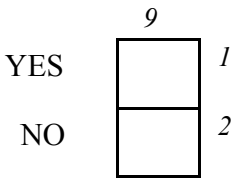
qualification?

IF YES, please write in 
Q. 2 (a) Please give the full title of your present job

(b) Brief description of duties

Q.3 Thinking of all aspects of your job, what would you say is the one most difficult or demanding aspect of it, if any?

(Please write in)

Q.4 While acknowledging the complexity of most jobs, do you consider the work you do is

(Please tick one box)

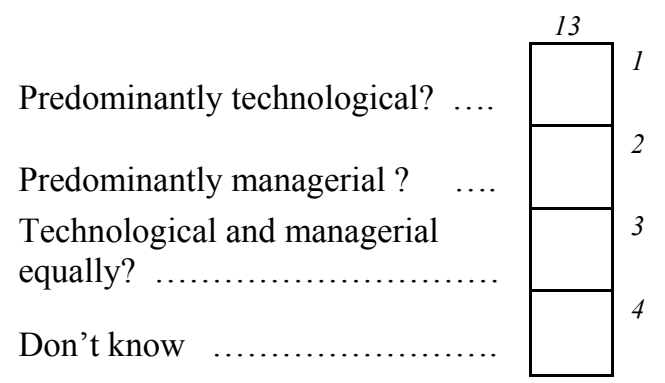

Q.5 Which of the following best corresponds to the level of responsibility which you have in your job?

(Please tick one box)

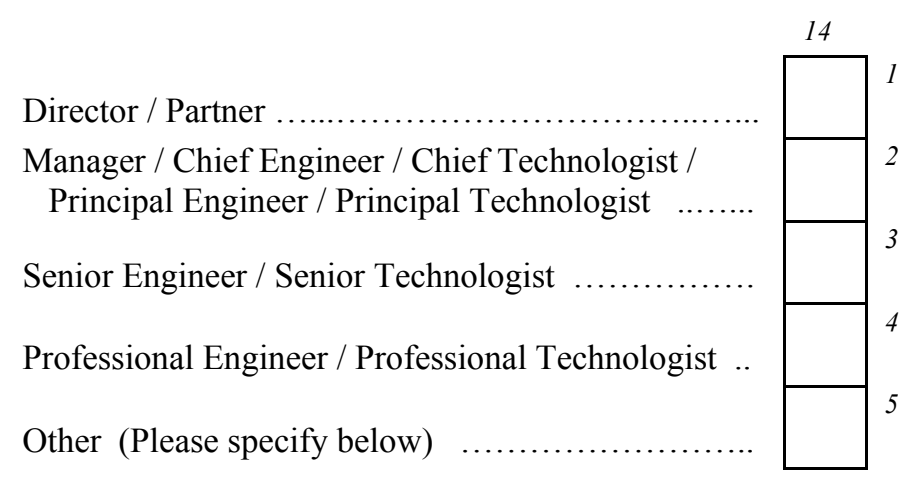


Q. 6

Here are some pairs of contrasting phrases which might be used to describe your job.

For each pair, please read both phrases before deciding which one best describes your job, then circle one number on each scale accordingly.

If you consider that one or other of the phrases is a very close description of your job, you should circle number 1 or number 7 . If one of the phrases is a fairly close description, circle number 2 or 6 . If one phrase applies only slightly more than the other, circle number 3 or 5 . If both apply equally, circle number 4.

a. I have a great deal of say in choosing between different work objectives to be adopted.

b. I have a great deal of say in decisions about production/ project goals and/or work schedules.

c. I co-ordinate the work of others by on-the-spot discussion and feedback as it progresses.

d. My own work is co-ordinated by on-the-spot discussion and regular feedback as it progresses.

e. I have freedom to adopt my own methods of work.

3

f. Unexpected problems rarely arise in my work

$\begin{array}{lllllll}1 & 2 & 3 & 4 & 5 & 6 & 7\end{array}$

7

I co-ordinate the work of others by advance regular 17 planning and programmes.

My own work is co-ordinated by advance planning and 18 programmes.

The methods of work I use are decided in detail 19 by someone else.

Unexpected problems frequently arise in my 20 work.

Most problems require

g. Most problems are solved according to known procedures

$\begin{array}{llllll}2 & 3 & 4 & 5 & 6 & 7\end{array}$

The next question (Q.7 facing page) refers to a list of skills and areas of expertise which people trained in the various branches of engineering might use. We would like to ask FOUR questions about each item on the list.

In COLUMN 'A' : $\quad$ Are you required to do this type of work FREQUENTLY as part or all of your present job? or

COLUMN 'B' : $\quad$ Are you required to do this type of work SOMETIMES as part or all of your present job?

In COLUMN ' $\mathrm{C}$ ' Did you receive any instruction in this area during your BASIC training to qualify as an engineer?

In COLUMN 'D' Have you received any formal training or instruction in this area SUBSEQUENTLY?

In COLUMN 'E' Which of these skills and expertise IN ADDITION TO THOSE YOU ALREADY USE in your present job (Column 'A') do you expect to require in your FUTURE career?

For each item, please TICK $(\sqrt{ })$ if your answer is 'YES'. Leave blank each item which you neither use in your present job, nor have had any training in, nor expect to require in the future. 


\begin{tabular}{|c|c|c|c|c|c|c|}
\hline \multirow{4}{*}{ SKILLS AND EXPERTISE } & & $B$ & \multirow{4}{*}{$\begin{array}{c}C \\
\text { INSTRUCTION } \\
\text { RECEIVED IN } \\
\text { BASIC } \\
\text { TRAINING }\end{array}$} & \multirow{4}{*}{$\begin{array}{c}D \\
\text { INSTRUCTION } \\
\text { RECEIVED IN } \\
\text { SUBSEQUENT } \\
\text { TRAINING }\end{array}$} & \multirow{4}{*}{$\begin{array}{c}E \\
\text { ADDITIONAL } \\
\text { REQUIREMENT } \\
\text { IN FUTURE } \\
\text { CAREER }\end{array}$} & \\
\hline & \multirow{2}{*}{\multicolumn{2}{|c|}{$\begin{array}{l}\text { REQUIRED IN } \\
\text { PRESENT JOB }\end{array}$}} & & & & \\
\hline & & & & & & \\
\hline & Frequently & Sometimes & & & & \\
\hline \multicolumn{6}{|l|}{ Costing, estimating } & 01 \\
\hline \multicolumn{6}{|l|}{ Project financing } & 02 \\
\hline \multicolumn{6}{|l|}{ Evaluate projects } & 03 \\
\hline \multicolumn{6}{|l|}{ Analyse project risks } & 04 \\
\hline \multicolumn{6}{|l|}{ Analyse corporate risks } & 05 \\
\hline \multicolumn{6}{|l|}{ Plan and control budgets } & 06 \\
\hline \multicolumn{6}{|l|}{ Company accounting } & 07 \\
\hline \multicolumn{6}{|l|}{ Corporate (business) strategy } & 08 \\
\hline \multicolumn{6}{|l|}{ Plan and schedule project } & 09 \\
\hline \multicolumn{6}{|l|}{ Plan new product } & 10 \\
\hline \multicolumn{6}{|l|}{ Patenting } & 11 \\
\hline \multicolumn{6}{|l|}{ Plan research } & 12 \\
\hline \multicolumn{6}{|l|}{ Plan design and development } & 13 \\
\hline \multicolumn{6}{|l|}{ Plan construction } & 14 \\
\hline Plan production & & & & & & 15 \\
\hline Plan maintenance & & & & & & 16 \\
\hline Plan stocks and materials distribution & & & & & & 17 \\
\hline Plan services & & & & & & 18 \\
\hline Marketing of products & & & & & & 19 \\
\hline $\begin{array}{l}\text { Marketing of consultancy, technical } \\
\text { services }\end{array}$ & & & & & & 20 \\
\hline Use of company law & & & & & & 21 \\
\hline Use of health \& safety law & & & & & & 22 \\
\hline Use of employment law & & & & & & 23 \\
\hline Use of consumer safety law & & & & & & 24 \\
\hline Draft contracts & & & & & & 25 \\
\hline $\begin{array}{l}\text { Negotiate contracts with client / } \\
\text { customer }\end{array}$ & & & & & & 26 \\
\hline Negotiate with supplier/contractor & & & & & & 27 \\
\hline Negotiate with employees & & & & & & 28 \\
\hline Negotiate with T.U. representatives & & & & & & 29 \\
\hline $\begin{array}{l}\text { Negotiate with public authorities (not } \\
\text { as customers) }\end{array}$ & & & & & & 30 \\
\hline Negotiate with senior management & & & & & & 31 \\
\hline Statistics & & & & & & 32 \\
\hline Operational research & & & & & & 33 \\
\hline Systems analysis & & & & & & 34 \\
\hline Organisation and Methods $(\mathrm{O} \& \mathrm{M})$ & & & & & & 35 \\
\hline Work study (methods study) & & & & & & 36 \\
\hline Data processing & & & & & & 37 \\
\hline Make formal presentations & & & & & & 38 \\
\hline Plan and chair formal meetings & & & & & & 39 \\
\hline Plan personnel requirements & & & & & & 40 \\
\hline Recruit and select personnel & & & & & & 41 \\
\hline Motivate others & & & & & & 42 \\
\hline Supervise others & & & & & & 43 \\
\hline Appraise personnel & & & & & & 44 \\
\hline Employee training - manual workers & & & & & & 45 \\
\hline Employee training - supervisors & & & & & & 46 \\
\hline Employee training - management & & & & & & 47 \\
\hline OTHERS ................ & & & & & & 48 \\
\hline 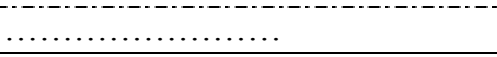 & & & & & & 49 \\
\hline
\end{tabular}


Q. 8 (a) To how many people are you directly responsible?

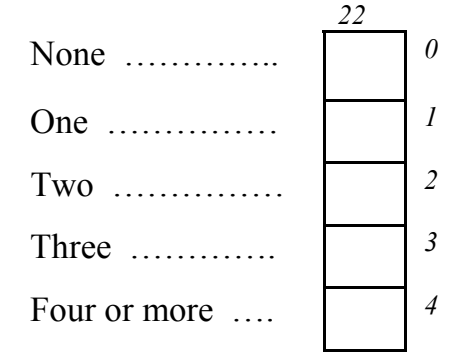

(b) What jobs do they have?

a

$\mathrm{b}$

(Please write in their job title(s))

c

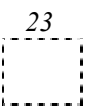

(c) Are there people to whom you give instructions but for whom you are NOT DIRECTLY responsible?

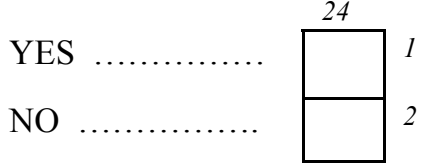
IF YES,

(d) What jobs do these people have?

(Please write in job titles of the main categories)

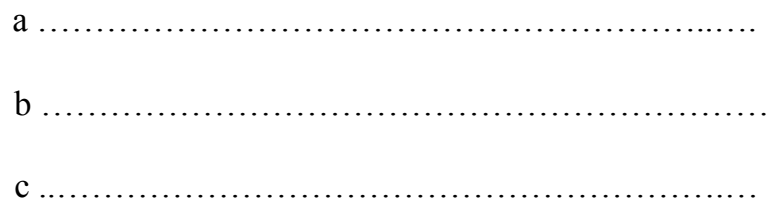

(e) For how many people's work are you DIRECTLY responsible? ( Your immediate subordinates only)

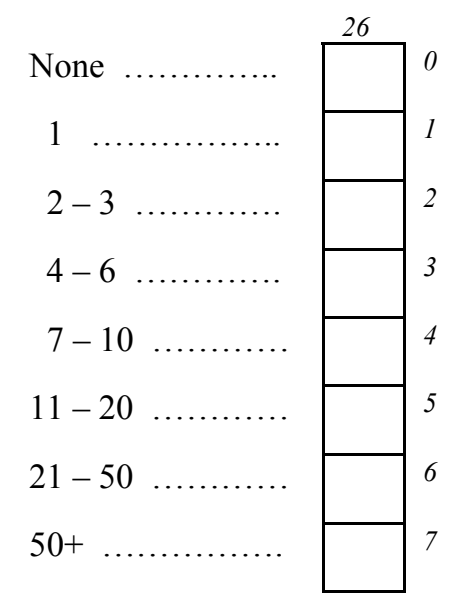

IF APPLICABLE,

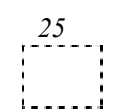

(Please write in how many and tick appropriate box)

(f) What jobs do these people have?

(Please write in job titles
a.
$\mathrm{b}$
$\mathrm{c}$

of the main categories) 
The various types of organisations which engineers work in may influence the managerial aspects of their jobs. The following questions, therefore, ask about the organisation for which you work.

Q. 9 Approximately how many people are

Employed at your own place of work?

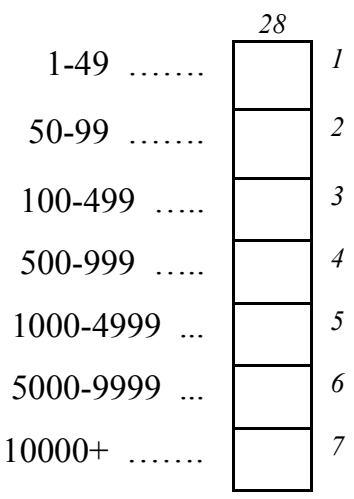

Q. 10 Is your place of work one office, one site or department of a larger organization or is it an independent organization?

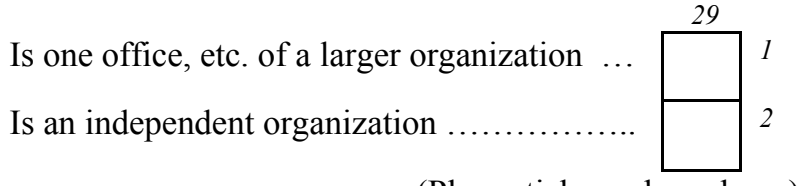

(Please tick one box above)

Years in
i) Organisation
ii) Job

Q. 11 How long have you been working

i) With your present organisation ?

ii) In your present job ?

$$
\begin{aligned}
& \text { (Please tick one box } \\
& \text { in each column) }
\end{aligned}
$$
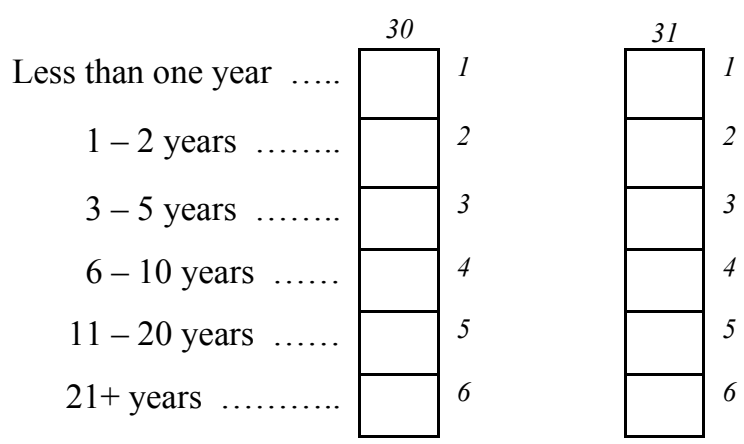

FINALLY, SOME QUESTIONS ABOUT YOURSELF

Q. $12 \quad$ (a) Your age

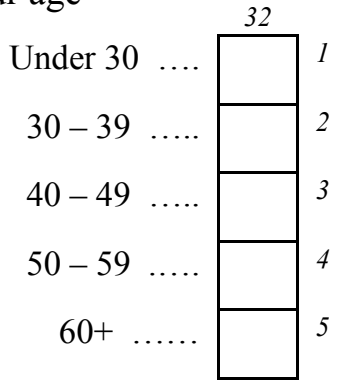

(b) Sex

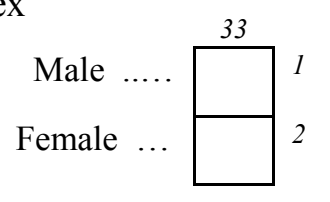


Q.13 (a) Are you expecting to change your job in the foreseeable future?

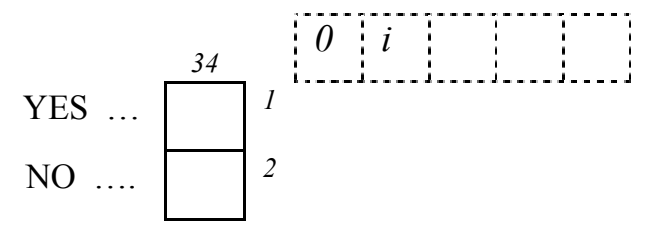

IF YES, (b) Are you expecting -

Promotion within the same organisation?

A transfer in the same organisation?

A move to another organisation?

A move to self-employment or consultancy?

Retirement

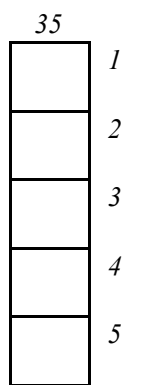

Q. 14 What are your management

Job Title

ambitions, in terms of job

title and responsibilities?

Responsibilities

Q.15 What support do you expect from the Institution to assist you in achieving these ambitions ?

YOUR GENERAL COMMENTS:

\section{THANK YOU VERY MUCH FOR YOUR HELP}

Would you like to have a copy of our report on this survey?

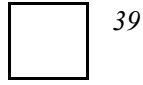

Would you like to take part in a follow up discussions of the results of this survey

to be organised by the Institution?

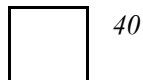

IF YES to either question above, please enter your name and address here:- 
Appendices p. 9

Post Code: ................. 


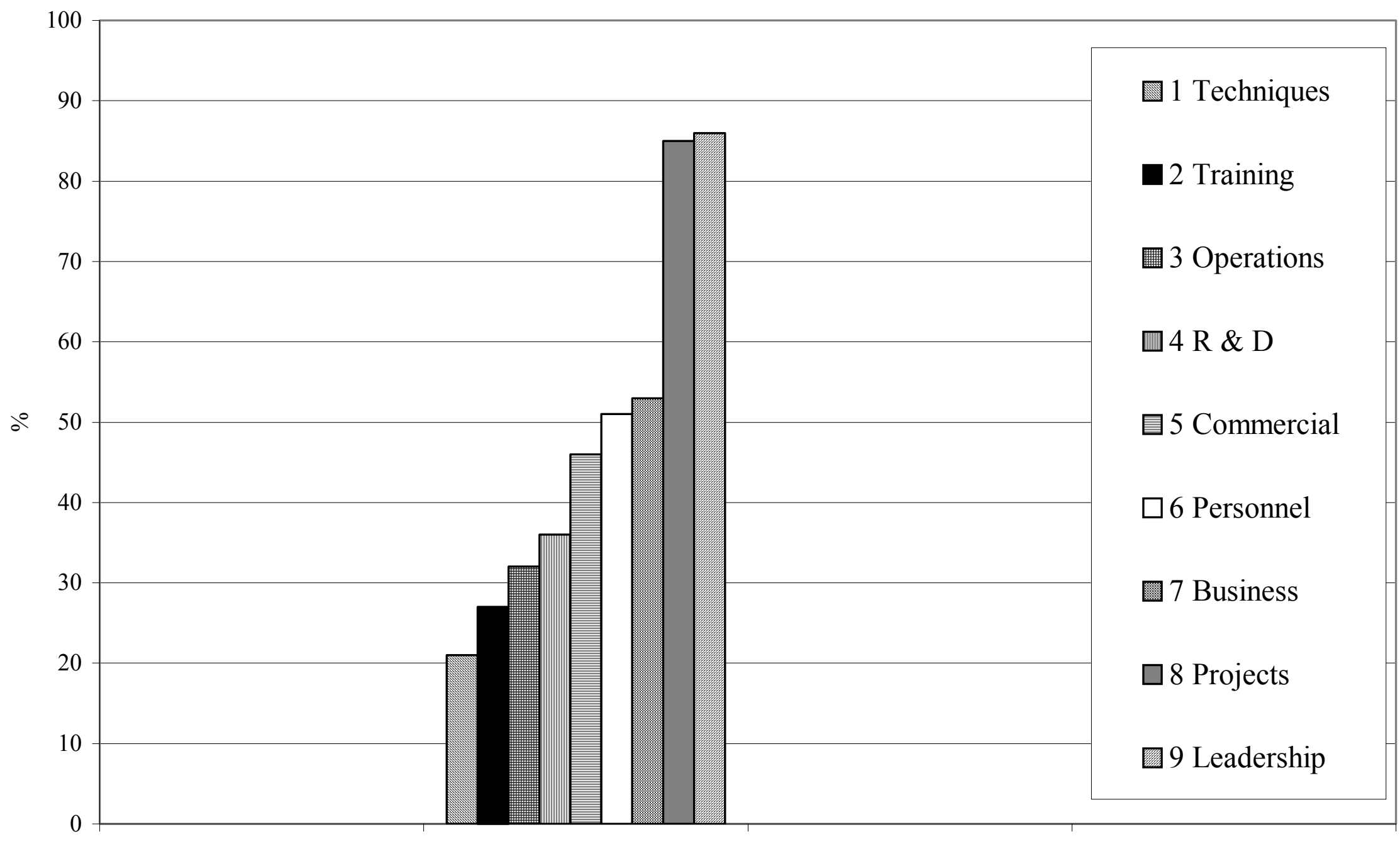

Figure 1 - Groups of Skills and Expertise Required by Chartered Engineers in Present Jobs Members of 10 Institutions 


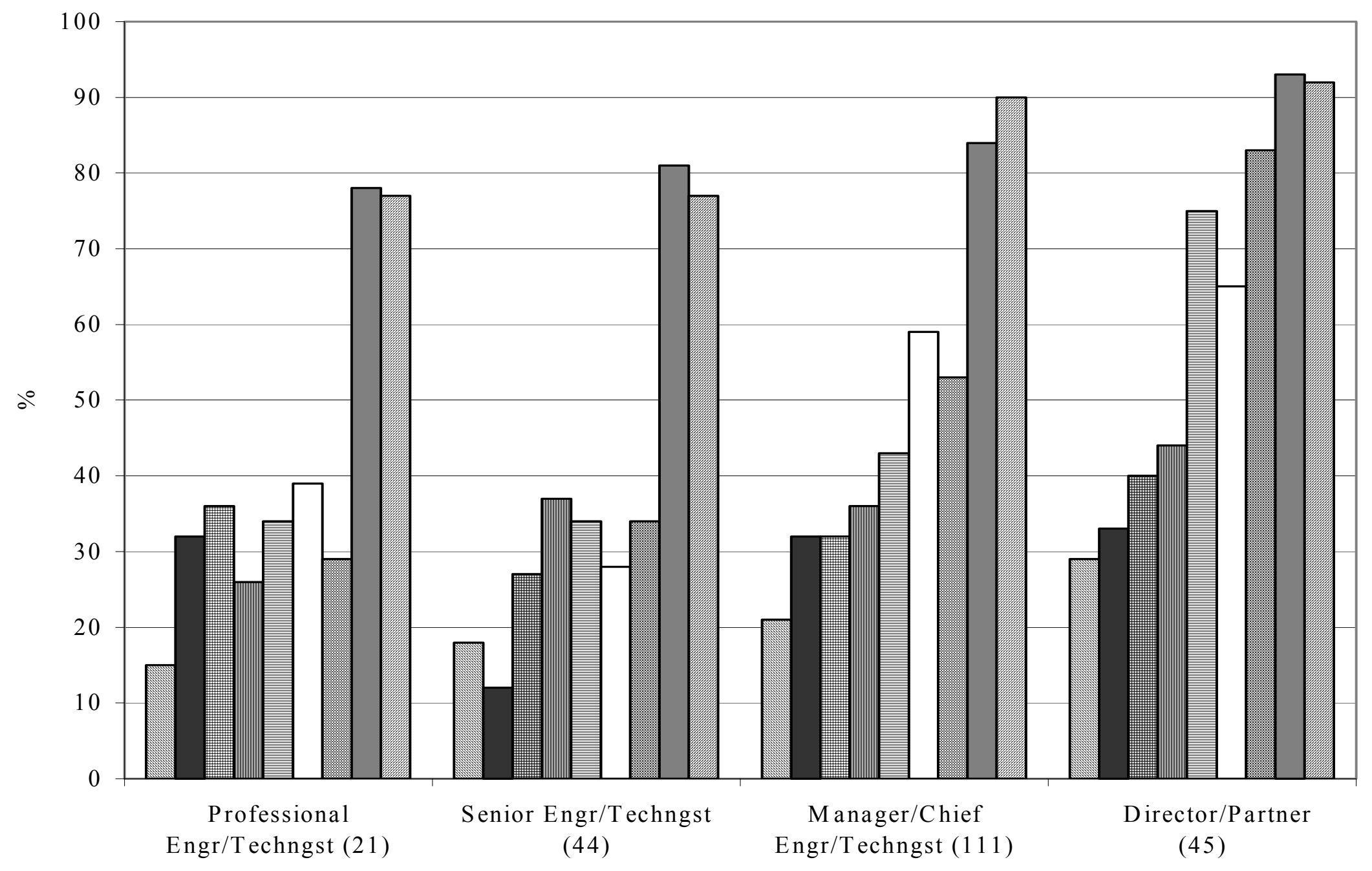

$\square 1$ Techniques

$\square 2$ Training

$\square 3$ Operations

$\square 4 \mathrm{R} \& \mathrm{D}$

$\square 5$ Commercial

$\square 6$ Personnel

$\square 7$ Business

$\square 8$ Projects

$\square 9$ Leadership

Figure 2 - Groups of Skills \& Expertise Required compared with Level of Responsibility 


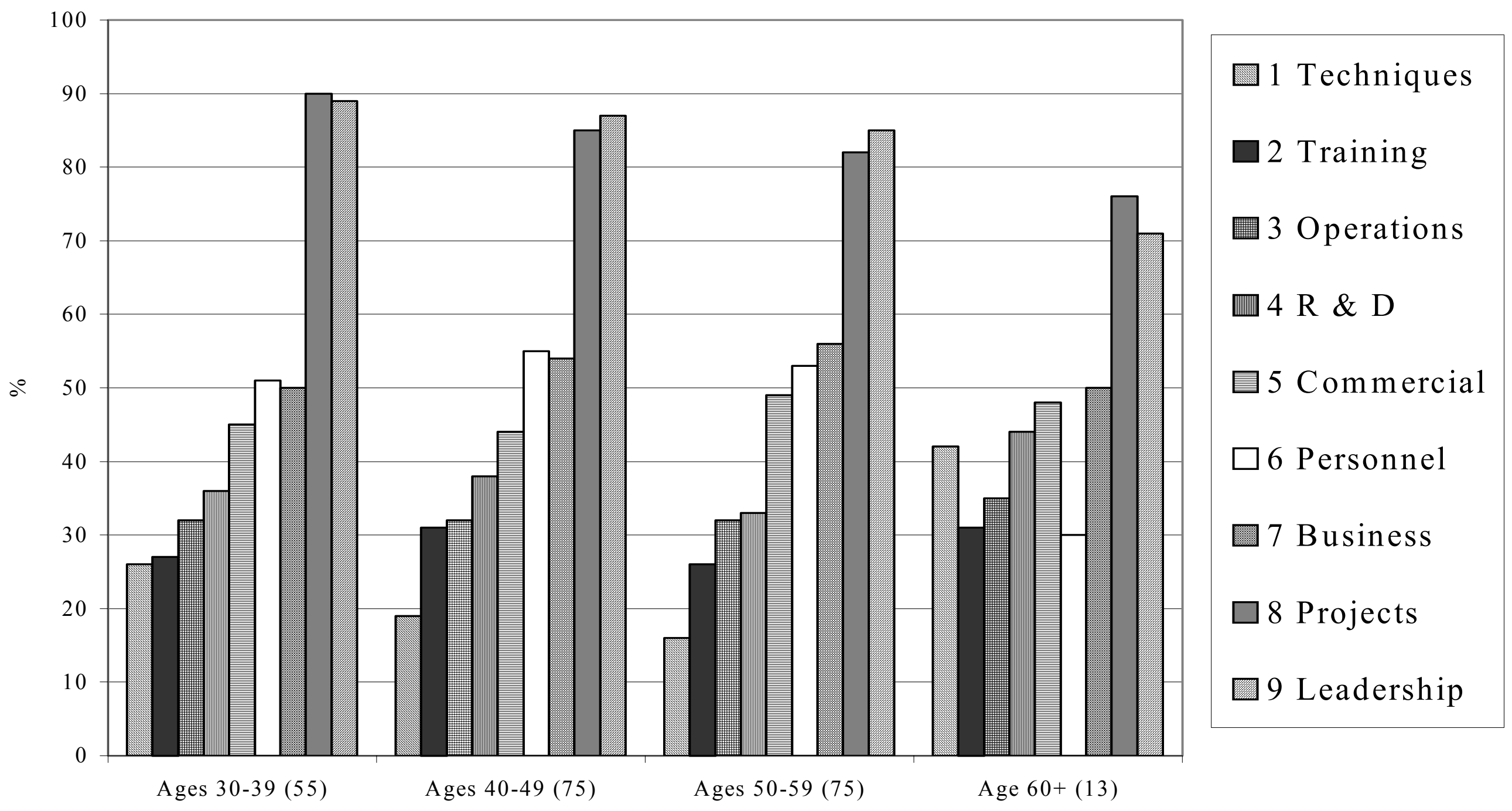

Figure 3 - Groups of Skills \& Expertise Required compared with Age 


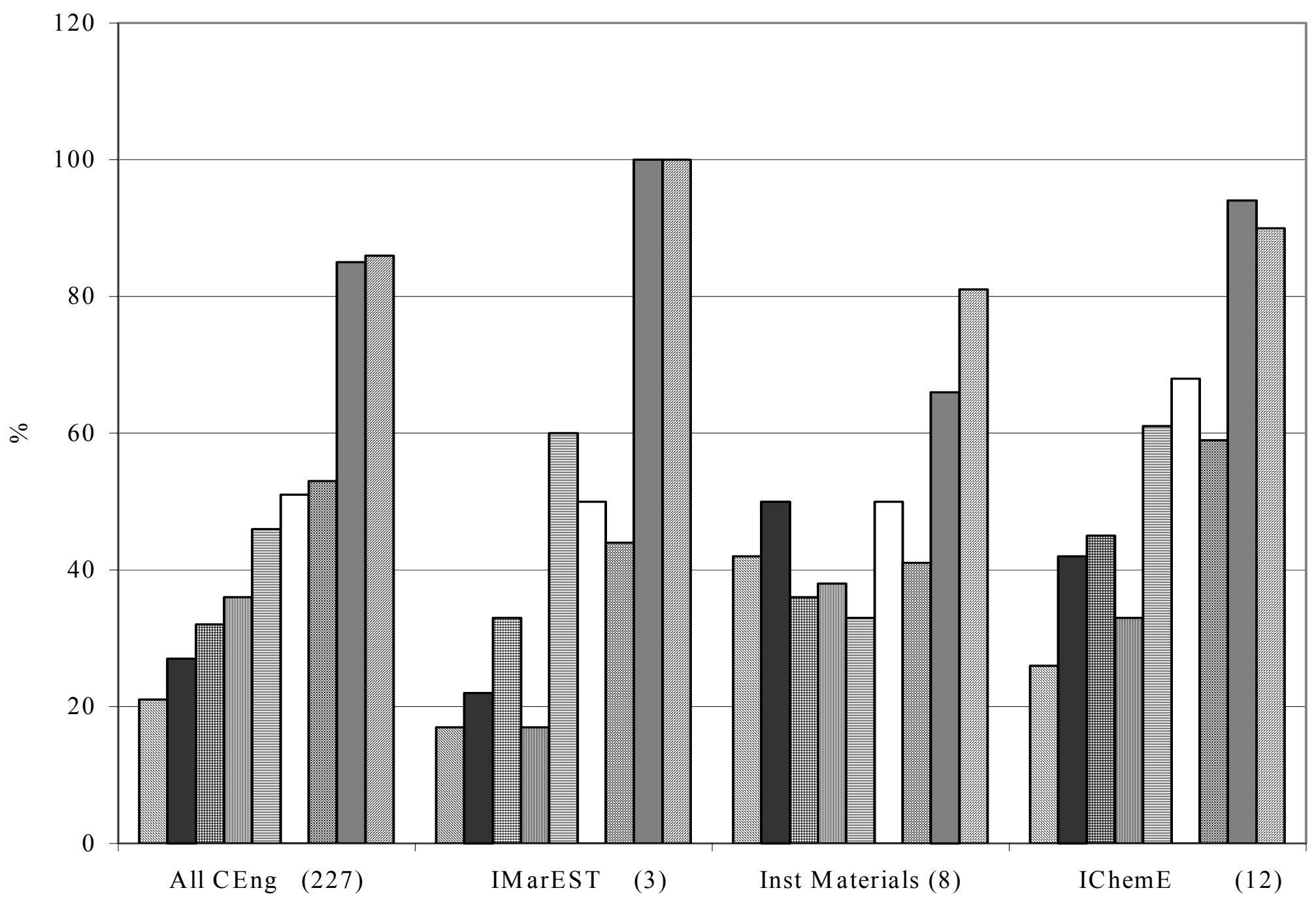

1 Techniques

$\square 2$ Training

$\square 3$ Operations

$\square 4 \mathrm{R} \& \mathrm{D}$

$\square$ 5 Commercial

$\square 6$ Personnel

$\square 7$ Business

$\square 8$ Projects

$\square 9$ Leadership

Figure 4 - Use of Groups of Skills \& Expertise by Institution Members I 


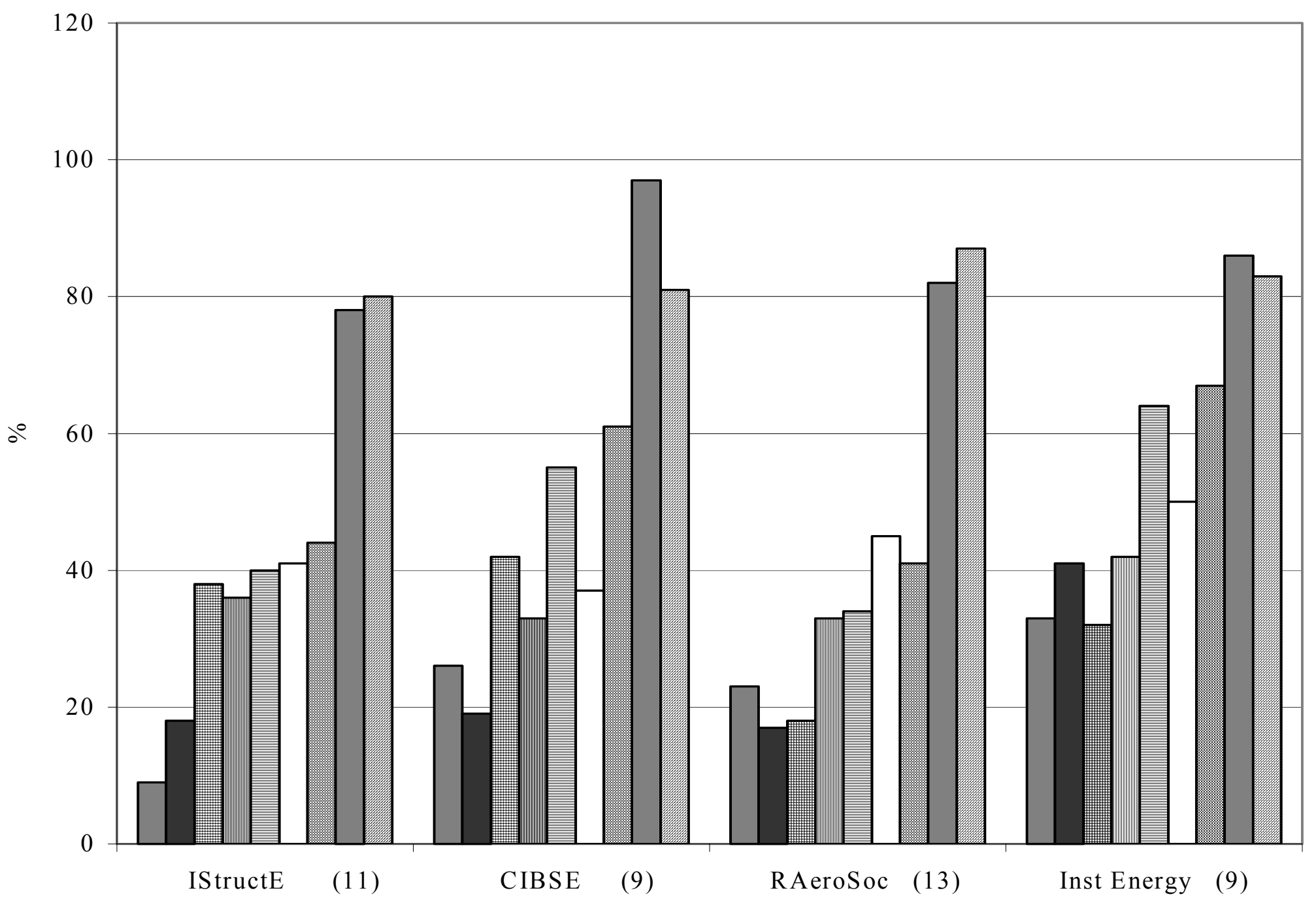

$\square 1$ Techniques

$\square 2$ Training

$\square 3$ Operations

$\square 4 \mathrm{R} \& \mathrm{D}$

吕 Commercial

$\square 6$ Personnel

$\square 7$ Business

$\square 8$ Projects

$\square 9$ Leadership

Figure 5 - Use of Groups of Skills \& Expertise by Institution Samples - II 


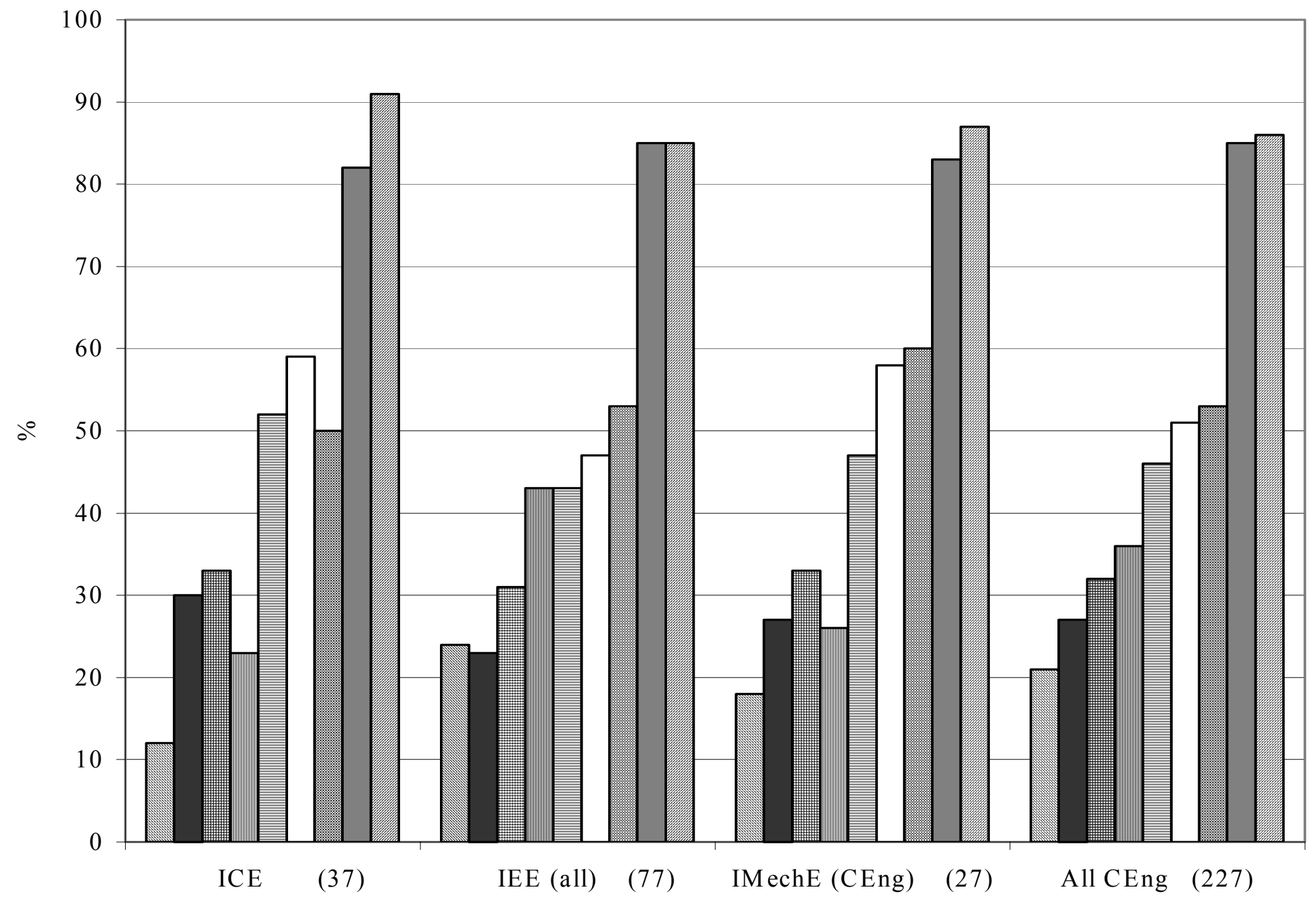

$\square 1$ Techniques

$\square 2$ Training

$\square 3$ Operations

$\square 4$ R \& D

邑5 Commercial

$\square 6$ Personnel

7 Business

$\square 8$ Projects

9 Leadership

Figure 6 - Use of Groups of Skills \& Expertise by Institution Samples - III 


\section{APPENDIX B}

ANSWERS TO Q. 3 ON MOST DIFFICULT OR DEMANDING ASPECT OF JOB

Defining engineering strategy in the light of business environment.

Ensuring that all relevant parties are involved in our process.

Organisational change to meet evolving business needs.

Financial management.

People management.

Managing people.

Need for rapid \& continuous change / improvement to remain viable.

Dealing with superiors. Dealing with staff.

Ensuring all managers \& supervisors understand the requirements of the specifications and the client understands what he has bought.

Managing a large number of diverse technical support services.

To lead the team through persuasion without appearing authoritative.

Bureaucracy (approvals from government, partners, etc).

Managing business changes.

People management.

Holding company together.

Making investigations into several tasks at once.

Management of my personnel.

Clarity of expression \& determination of the vital clues over a range of possible causes of an accident / breakdown.

Organisational development - building from scratch a significantly sized department.

Ensuring compliance of teams with legislation with production environment.

Just one of me (!) and the very wide range of subjects within duties.

Redundancy.

People related issues.

'Selling'.

Predicting when aspects of work will be complete, to issue notice of "testing" as required by

contract. Failure to issue correct notice has major contractual implications.

Managing income stream / overheads.

Wide variety of disparate issues. Duties varying from visionary to technical detail.

Specification of new products.

Time management.

Winning new business.

Resourcing key skills.

Extracting information from colleagues which supports a clear understanding of the overall picture.

Balancing long and short term resource allocation having regard to skills requirements, personal attributes and the individual's development needs.

Time management.

Understanding details of ever changing telecommunications technology.

Managing IT developments.

Interaction with Senior Company Management.

Being called in out in the middle of the night and solving problems.

Persuading the organisation to take on more efficient management practices.

Providing my product on time, to cost and to the required quality with requirements constantly changing and short timescales.

Trying to match suitable staff with project needs in order to meet programmed delivery dates

Investigation into wrongside (unsafe) failures.

People relationships.

Persuading design and development staff that Safety is important.

Motivating others.

Organisation of staff.

Following the plan.

Changing organisational behaviour.

The people. 
Getting engineers to understand the concepts of running projects to budgets !

Coming up with novel solutions.

Meeting deadlines.

Getting designers to understand the principles of 'Smart' requirements and apply them to unique, unambiguous, singular and solution-independent system requirements.

Meeting the timescales for project work.

Getting contractors to understand that safety related systems need special design, development etc.

Keeping my team fully occupied at all times.

Managing resources including people - academic staff, administrative staff, students and clients.

Fighting the company system to ensure the planned resource and material are available at the right

time in the right place.

Amount of time spent away from home on business.

Developing realistic investment costs when incomplete information available at time of project

sanction.

Commissioning a sewage works.

Frequent changes in customer requirements (demands).

Sterile manufacture.

Becoming technically credible across a large range of topics.

Managing a diverse team of traders.

Coordinating (with others) the group sales pipeline.

Multi-interfacing with so much non-core business outsourced.

Managing a large workload with limited resources.

Understanding cultural differences and defining implementation logic.

Getting business to accept the need for change.

Frustration at decision processes within a multi-national.

Balancing attention to detail with limited resources against risk of an oversight.

Training graduates \& academics in aspects of safety law that they must address.

Correcting mistakes made by other people.

Obtaining continued commitment to the system from senior management.

Thinking outside of the box and changing mindset.

Creative research.

Fund raising.

Coping with continuous change to computer systems, company organisation and admin - in fact all the things which get in the way of doing my present job .

Satisfying business and customer demands at the right cost.

(a) Performance of suppliers. (b) Competing for resource not directly in my control.

Recruitment of systems engineering staff.

Task / responsibilities definition.

Getting other departments / agencies to do their work in a timely fashion and correctly.

Preparation of bid documents.

Managing transnational relationships.

The political dimension. Trying to help other companies while no being seen to intrude - consultancy.

Making my team flexible enough to deliver our customers requirement.

Internal justification of prioritising my effort.

Maintaining client demand for the service provided.

Breadth of skill and knowledge for strategic planning.

Balancing resources \& workload.

Time management.

Accommodating all views of public perspective.

The diversity of designs involved with.

Workload and pressure to meet deadlines.

Having time to do everything.

Juggling multiple projects.

Identifying a new method of working \& getting it operational.

Demanding - Travel and hours worked.

Difficult - Successfully winning new work.

Partner alignment. 
Ensuring continuity of workload.

Budgets.

Dealing with managers (team leader and above, 'the top') who do not know very much about bridge engineering. It is very frustrating.

Intercultural management issues.

Structural design.

Achieving programme targets with too little information.

Working with businesses and business organisations whose main sector is not transport or engineering.

Not having ultimate executive control as a consultant.

Assessing clients' requirements.

Political interference.

Delivering projects with ever reducing staff numbers.

Staff motivation and management.

Managing those not directly responsible to me.

Managing high level of "on demand" service provision with limited resources.

Keeping up with legal and regulatory requirements in a politically sensitive industry.

Obtaining the quality of subcontractors to carry out the work to the required standards.

Keeping up with current British Standards \& other technical standards / literature.

Providing client satisfaction while meeting own company's profit targets.

Maintaining positive relationships with enterprise representatives.

Dealing with other professors.

People management skills.

Resolving conflicting agendas under time / budget pressure.

Keeping staff and clients happy.

Meeting project deadlines when timescales and resources are short.

General management.

Personnel management.

Being right ! i.e. identifying the probability component in risk assessment.

Writing reports.

Keeping up to date.

Immediacy of the decision making on many occasions.

Strategy - Direction.

Managing research projects.

Convincing potential clients of their need for our services.

Working with other consultants who have poor knowledge or understanding.

Sales.

Technology and innovation.

Complying with various clients briefing documentation.

Changing and increasing legislation regulations etc.

Planning and managing resources to achieve a first class service.

Forcing a quality installation from builders intent on meeting programmes.

Impossible / unrealistic targets.

Marketing.

Generating sufficient workload.

Making a profit.

Defending claims from contractors who regard PI insurance as a source of revenue.

Coping with lack of infrastructure, eg no electricity, phone etc.

Time management in dealing with students.

Time management.

Being able to do the quality of work in the budget \& time available.

Juggling conflicting demands and unrealistic timescales.

Keeping up to date with changes in design codes \& procurement methods.

Understanding \& applying new design standards.

Keeping up to date / leading edge.

Persuading people to do what they don't want to do.

Maintaining up to date knowledge \& compliance with legislation. 
Morale - it can be difficult in the face of the manufacturing climate.

Financial operations side of product dev / setting up contracts with sub-contractors.

Balancing conflicting and time consuming roles.

The motivation and development of staff.

Prioritisation and delegation, including follow-up.

Finding sufficient qualified, experienced staff.

Time management.

Moving from technical work to managerial.

Programme management.

Cost control (estimating engineering $\mathrm{m} /$ hours).

Trying to keep track of over 70 graduates !

Everything in running a business !

Dealing with main contractors.

Meeting customer expectations.

Business development.

Satisfying a multitude of customer requirements with limited resource.

Flexibility.

Ensuring the design is fit for purpose.

Major fleet sales contracts overseeing sales from enquiry through production to delivery.

Time and volume.

Supervising and managing staff.

Teaching.

Creativity.

Long hours.

Dealing with awkward customers.

Obtaining consensus from all parties to a single set of plans.

Financial planning.

Admin' ie invoicing, pricing, tax and VAT.

Being proactive all the time - never being able to take a back seat.

Managing the expectations of others.

Planning for the unexpected whilst having minimal contingency time.

Project management involving multi-disciplines and suppliers.

Clinical understanding of use of devices.

Obtaining information in a politically sensitive area.

Planning new courses.

Discipline of children.

Finance.

Policy development and ensuring an intellectually respectable basis exists.

Managing uncertainty - technical Risks vs timescales.

Translation of operational requirements to scientific / technical requirement - Assessment of deliverables.

Management of people.

Project management.

Strategic direction.

Persuading technical managers to improve their management skills.

International collaboration with Continental company, their MOD and politicians.

Balancing competing time demands.

Briefing senior officers / seminars.

Problem solving.

Volume of paperwork.

Teaching adults.

Understanding medical certification requirements in all major markets.

Specification interpretation.

Assimilation of information, decisions and dependencies across a range of business units, disciplines, technologies.

Huge and unpredictable variations in workload, and the variety of that workload. (It's also one of the most satisfying aspects!). 


\section{APPENDIX C}

\section{SCALES FOR ASSESSING VARIETY OF JOBS OF PEOPLE DEALT WITH}

Question 8 in the questionnaire included questions on the range of jobs of the people that respondents directly reported to, gave instructions to and were directly responsible for.

The respondents' answers on the range of jobs were assigned a numerical value on a scale according to the number of different jobs or disciplines represented, following the method used in the earlier surveys. In the case of superiors, their level of responsibility was taken into account if the respondent reported direct responsibility to two or more superiors with distinct responsibilities. For example, a construction manager responsible to the managing director and the engineering director of a process plant designer and supplier's firm was assigned to point 2 on the scale; a principal design engineer responsible to a technical director, chief engineer of the division and the manager of the department was assigned to point 3 on the scale.

Similarly, the respondents were placed on the scales for jobs of people to whom they gave instructions and people for whom they were directly responsible according to the number of different jobs or disciplines represented. 0 on the scale represented responsibility for secretarial or ancillary staff only. A general manager directly responsible for 3 senior commercial officers and a commercial manager was placed at point 1 of the scale, because, although two distinct levels of responsibility are represented they are in a single field of expertise. A general manager responsible for giving instructions to an insurance division, lawyers and accountants was placed at point 3 of the scale for this question. A civil engineer working as a contacts manager reporting direct responsibility for contracts engineers, solicitors, secretaries and clerical staff was placed at point 2 of the scale, i.e. 1 point for contracts engineers and 1 for solicitors and 0 for secretarial staff. An engineer responsible only for posts in a road division of a municipal authority was assigned to point 1 on the scale. A principal municipal engineer responsible for resident engineers, clerk of works, quantity surveyors and clerks was assigned to point 3, a chemical engineering lecturer responsible for research students to point 1 , and an aeronautical engineering manager giving instructions to a works manager and a chief buyer to point 2 on that scale and to point 3 on the scale of jobs for which he was directly responsible: chief projects engineer, chief inspector and print room supervisor.

Thus, the higher the point on the scale of any individual, the greater the range of disciplines or branches of engineering with which he or she is involved in communicating. It is taken that such communication across the boundaries of different disciplines require skills and experience of a higher order than those required in communicating with persons with the same professional or vocational background. 


\section{APPENDIX D \\ ANSWERS TO Q.15 ON SUPPORT EXPECTED FROM INSTITUTE / INSTITUTION / SOCIETY IN ACHIEVING MANAGERIAL AMBITIONS}

Maintain CPD (.. unreadable).

Communication on mgt. Programmes available.

Better support for senior technical managers.

Job adverts in Professional Engineer.

I expect none.

More higher management content to magazine, etc.

None. I don't think the Institution has been very helpful to Engineers in furthering Engineering as a profession!

Updating.

Maintain standards of Engineers. Represent Engineers to Government.

Provision of management training courses.

Notification of legislation changes.

Course and conferences.

Good technical papers.

Not sure at present.

Forum for industry networking through topical technical seminars etc.

Good technical information \& publications. Appropriate conference \& seminars.

None, really.

Not a lot.

Backup for consultancy / qualifications in case I get made redundant.

Opportunities for professional development.

CPD information, career progression advice.

Relevant meetings and literature on developing areas of power engineering and the opportunity to meet and network with other professionals and potential clients.

Consultancy career advice.

Seminars, contacts (networking), updating on technical advances, course (at somewhat less expense that the current course rates if I am to finance this myself). Continued and improved use of the PN's to provide these.

Access to relevant information.

Continued Professional Development.

Briefings through articles in journals.

Further provision of engineering management related meetings. Mentoring/training support of engineers to IEE standards.

Keeping me up to date on technical, safety and contractual issues related to electrical engineering. Why not make the results of this survey electronically?

I expect little direct support. I do expect to use the Professional networks to gather key information, etc.

Have not considered this.

As a source of technical and management information.

Nothing other than general industry awareness.

Promote the abilities of engineers in managing businesses.

None (although I read their publications, which, along with the IEEE's, keep me generally informed.

On-line reference library and pdf versions of tech magazines.

None. It doesn't seem to have any support for engineers working at my level or in my technical discipline.

Help to develop my engineering skills \& expertise.

Library facilities, CPD courses.

Support from colleagues to help achieve aims and resources.

Access to any relevant materials and courses with the ability to request information on services, and the services of people, that may be required.

Expecting little results in no disappointment.

Contacts. 
To improve the profile (\& money) of chemical engineers to levels..in Europe \& US.

Good networking opportunities. Affordable training for self-employed.

Limited - keeping me abreast of the industry \& technology.

Appropriate training courses.

Courses on contract / commercial sales \& marketing / project management.

More of the same. The Institute is already doing a good job supporting the .. industry.

Suitable management courses on CD ROM' etc.

No more than at present !!

Training courses. Networking.

None directly.

None at present.

Direction as to useful courses / qualifications and the future.

On-the-job training. Gradually more responsibility.

None.

Industry knowledge through magazines and conferences.

Networking. Industry awareness.

Keeping abreast of latest aerospace news. Conferences.

Professional training ie Airworthiness Course.

What support can I expect?

NCE useful for gaining general knowledge.

Ensure course providers offer a varied range of courses.

Ensure that there are sufficient engineers for me to be responsible for.

Programme / course / web pages on starting or running your own civil consultancy.

More support activities for mid career (35-45) engineers.

Expansion of the business centre at the Institution out of the dark basement + lap top connection

points.

Targetted training.

Information on current industry practices / best practice.

Background information through periodicals and presentations.

By providing better 'education' to senior member and non-member managers about what they are managing .. and promoting the image and importance of the engineer.

Raise professional profile.

None.

I am a realist. None as usual !

Dissemination of information on technical developments and practice.

Information / training for staff / members on change management, e.g. such as the book "Who

Moved My Cheese ?"

Information on trends, standards, legal changes, etc. Some professional / business info, training

courses.

Institution is stuck in the last Century. Should be more like BMA.

I expect none.

To set the agenda for public debate about infrastructure and by doing so control the influence of the money men.

Continue to drive for increased recognition for the profession.

I don't really expect any support from Institution.

Keep abreast of current developments and best practices.

Networking; continuing professional development.

CPD. Networking. Professional status.

Access to appropriate training (which is quite good).

Not relevant.

Institution increasing its professional status in UK.

Unfortunately the Institution cannot help me, other than the provision of technical information and guidance.

Good sound technical advice and an open community for job opportunity.

Promote the image and necessity of professional structural engineers.

A more sensible work load as I progress my managerial skills.

Leading edge updates. 
CPD opportunities.

Technical support and sharing best practice.

Introduction of MPD's, maintenance of goals \& level, technical bulletins.

Annual personal development appraisal.

Guidance on management programmes to progress through career. To achieve Fellowship status Senior management training.

I expect the Institute to raise the profile of engineers so that engineers are regarded as highly as other professionals (accountants, doctors, etc).

CPD, workshops, networking, forums.

Training.

Professional indemnity $\&$ other insurance scheme assistance (i.e. discounted focussed schemes). A small amount of management training.

Managing people does not come naturally to all. More 'general' rather than 'technical' personal development courses.

Keeps me up to date with latest tech.

Nothing. The Institute is geared towards SME's i.e. Educational/Gov' organisations and has little relevance to small business.

Professional recognition \& consistency.

Networking. Technical support.

Suggestions?

Knowledge - Access to people with similar expertise \& experience.

More help !

Perspectives on the challenges of successfully implementing technology solutions. 


\section{APPENDIX E}

\section{REPONSES TO INVITATION TO GIVE GENERAL COMMENTS}

Please don't lower standards for entry to enable more people to join. If you do this there's no point in being a member.

Current job has direct responsibility for a full shift team 'during silent hours' nut not between 08.00 and 16.00 ! Can lead to confusion for some team members. Therefore I am the manager focus figure at all times.

Although I am CEng,..., I have never to become a Member of my first Institution. I went to America soon after graduation \& graduate apprenticeship \& could never find a member to propose \& second me.

Keep modernising and attracting youngsters.

My present role maybe somewhat unusual as I am on secondment in Japan. I am responsible technically for a project, but not directly for the team members - a result of the language barrier.

At the moment my professional work has entered a cul-de-sac in that I am not using my skills and experience to any great extent. However my rewards and benefits are good and that, coupled with currently depressed state of the communications industry, makes for little incentive to seek a move for the moment.

I have reached age (over 50) where I have found that many companies do not employ new starters. Therefore, it is not worth me investigating the job market.

Some additional legal advice would be welcomed, for both supporting members in personal problems and to advise managers to help resolve personnel, employment, contractual and company issues. Perhaps a subscription based service to members.

The default 'send' button at the bottom of this form caused me to submit a partially completed form by inadvertently pressing the 'return' key.

I am at the final stages of an MBA sponsored by my company. My dissertation addresses organisational behaviour in a sales environment.

Long table difficult to fill in when the headings have scrolled off the top of the screen.

No questions about the politics of management? Relationship abilities ?

Can you send a pdf of the report to me. I'm trying to reduce the paper on my desk...

Knowledge of developments in technology and in processes, and current best practice.

With reference to Q15, the question is: why do I still bother with membership ?

The Institution must change to help all its members progress eg creche at courses/lectures, womens network (there are many more working mothers in the I that I suspect its male dominated senior membership realise).

The activities of the Institution tend to be directed towards a number of specialised aspects of electrical engineering. There is little for consultants .. who operate over a wide range of applications.

I am very much in support of this initiative. You should know about our recent new MBA course aimed at professional engineers - as engineering business managers.

Mass redundancies from 'special' steel industry. Very difficult to find work if 60 or older.

I feel very strongly that engineers \& scientists should be given at east a basic training in health, safety \& environment law, and be introduced to the concepts of risk management. It is very difficult to introduce these ideas to engineers 10,20 or more years after they have entered work - they simply do not see them as issues.

I believe training in planning/costing/risk management should be included in degree courses. I use these (along with many working in engineering) regularly.

Most training I have received has been "on the job" experience.

"Management" is all part of "Engineering".

Much of my basic training at university is used to solve and understand any engine issues especially performance related issues.

I found within large organisations that management positions require removal from engineering activities to a certain extent. I didn't do an engineering degree to become a manager so how do you progress ? I became Director of my own consultancy 6 years ago but thanks to IR35 taxation this is no longer viable and next month my business ceases to trade. I love aerospace engineering but until the respect and rewards for engineers are forthcoming I will resent the career choice I made. 
I would be grateful if the Institution could inform me of the support it can give during my career development.

The standards of education, training and examination must be kept high

I moved away from straight engineering 10 years ago and focused on general management.

Quite a difficult form to fill in, e.g. Q6 and Q7!

You would have had better response if envelope had been pre-paid postage.

Obtaining the quality of subcontractors to carry out the work to the required standards.

My work tends to oscillate between contract and freelance.

After 39 years I am beyond job titles and pecking orders. I enjoy working with and meeting new people, young and old .....

Q.7 makes no reference to technical skills \& expertise; such skill \& expertise may form a lesser part of my actual work but lies at the heart of most of it.

The survey could awareness of need and not need itself (of management / technical skills).

CPD through technical meetings / seminars.

Engineers are still generally under-valued in society.

Management training in industry is poor.

It is difficult to complete this questionnaire for members in education. Management skills are extremely important when one is an infinite resource for one's employer. However the skills necessary to motivate students and to help them manage their learning are priceless.

The cost of Institution run seminars / courses is prohibitively expensive for small businesses, particularly when travel, accommodation \& loss of earnings is taken into account. CPD in the conventional sense is not a viable option.

My job is unique; I doubt if my input will help with your survey. The job is politically important, but no commercial organisation would be prepared to fund it.

I welcome this initiative.

Instances of potentially sound developments failing as a result of badly managed implementation are all too common. 


\section{APPENDIX F \\ COMPARISON OF DATA RECEIVED FROM CHARTERED AND NON-CHARTERED MEMBERS OF THE INSTITUTION OF MECHANICAL ENGINEERS}

The purpose of the appendix is to compare the responses on managerial skills and expertise used in their present jobs by the samples of Chartered and non-Chartered members of the Institution of Mechanical Engineers. First we compare some of the general data from them.

\begin{tabular}{|c|c|c|}
\hline Age & $\%$ & $\%$ \\
\hline Under 30 & & 10 \\
\hline $30-39$ & 26 & 29 \\
\hline $40-49$ & 22 & 38 \\
\hline $50-59$ & 41 & 24 \\
\hline $60+$ & 11 & \\
\hline
\end{tabular}

Type of qualification

\section{Chartered IMechE Non-Chartered members \% IMechE members \%}

\begin{tabular}{|l|c|c|}
\hline University degree & 74 & 43 \\
\hline CNAA degree & 4 & \\
\hline Diploma in Technology & 4 & \\
\hline Professional Institution examination & 15 & 19 \\
\hline HND & 4 & \\
\hline HNC & & \\
\hline NVQ & & \\
\hline Other & & \\
\hline
\end{tabular}

(The percentages are not mutually exclusive)

$\begin{aligned} & \text { Hold any other higher educational } \\
& \text { qualification? }\end{aligned}$
\begin{tabular}{|c|c|c|}
\hline Yes & 48 & $\%$ \\
\hline
\end{tabular}

$\begin{aligned} & \text { Type of other higher educational } \\
& \text { qualifications }\end{aligned}$
\begin{tabular}{|l|c|c|}
\hline MBA & $\%$ \\
\hline Other Management & 15 & \\
\hline $\begin{array}{l}\text { Masters degree in Engineering, } \\
\text { Technology, Mathematics or Science }\end{array}$ & 19 & 19 \\
\hline $\begin{array}{l}\text { Postgraduate Diploma / Certificate in } \\
\text { Engineering / Technology / Applied } \\
\text { Science }\end{array}$ & 7 & 5 \\
\hline PhD & & \\
\hline
\end{tabular}




\section{Chartered \\ IMechE \\ Non-Chartered \\ members \\ IMechE \\ Technological vs. managerial content of \\ $\%$ \\ members \\ $\%$ job}

\begin{tabular}{|l|c|c|}
\hline Predominantly technological & 19 & 24 \\
\hline Predominantly managerial & 56 & 14 \\
\hline Both equally & 26 & 62 \\
\hline
\end{tabular}

Level of responsibility
\begin{tabular}{|l|c|c|}
\hline Director / Partner & 41 & 5 \\
\hline $\begin{array}{l}\text { Manager / Chief Engineer /Chief } \\
\text { Technologist / Principal Engineer / } \\
\text { Principal Technologist }\end{array}$ & 48 & 48 \\
\hline Senior Engineer / Senior Technologist & & \\
\hline $\begin{array}{l}\text { Professional Engineer / Professional } \\
\text { Technologist }\end{array}$ & 11 & 24 \\
\hline Other & & 5 \\
\hline
\end{tabular}

Most difficult or demanding aspect of job

$\% \quad \%$

\begin{tabular}{|c|c|c|}
\hline Industrial relations & & \\
\hline People management & 33 & 24 \\
\hline Communications & 4 & \\
\hline Control & 11 & 19 \\
\hline Keeping up with new developments & & 5 \\
\hline Dealing with other senior managers & 19 & \\
\hline Technical & 7 & 5 \\
\hline Business & 7 & 14 \\
\hline Political interference, bureaucracy & 4 & \\
\hline \multicolumn{3}{|l|}{ Risk } \\
\hline Improvements and change & 11 & 5 \\
\hline Safety & & \\
\hline
\end{tabular}


Table F1

\begin{tabular}{|c|c|c|}
\hline $\begin{array}{l}\text { SKILLS AND EXPERTISE } \\
\text { REQUIRED IN PRESENT JOB }\end{array}$ & $\begin{array}{c}\text { Chartered IMechE } \\
\text { members } \\
\%\end{array}$ & $\begin{array}{c}\text { Non-Chartered } \\
\text { IMechE members } \\
\%\end{array}$ \\
\hline Costing, estimating & 82 & 91 \\
\hline Project financing & 78 & 76 \\
\hline Evaluate projects & 89 & 86 \\
\hline Analyse project risks & 85 & 86 \\
\hline Analyse corporate risks & 56 & 52 \\
\hline Plan and control budgets & 78 & 81 \\
\hline Company accounting & 44 & 19 \\
\hline Corporate (business) strategy & 63 & 33 \\
\hline Plan and schedule project & 78 & 91 \\
\hline Plan new product & 26 & 48 \\
\hline Patenting & 7 & 24 \\
\hline Plan research & 22 & 52 \\
\hline Plan design and development & 48 & 71 \\
\hline Plan construction & 33 & 48 \\
\hline Plan production & 30 & 24 \\
\hline Plan maintenance & 44 & 33 \\
\hline Plan stocks and materials distribution & 22 & 19 \\
\hline Plan services & 37 & 43 \\
\hline Marketing of products & 37 & 33 \\
\hline $\begin{array}{l}\text { Marketing of consultancy, technical } \\
\text { services }\end{array}$ & 37 & 29 \\
\hline Use of company law & 41 & 19 \\
\hline Use of health \& safety law & 78 & 62 \\
\hline Use of employment law & 59 & 29 \\
\hline Use of consumer safety law & 15 & 24 \\
\hline Draft contracts & 52 & 33 \\
\hline $\begin{array}{l}\text { Negotiate contracts with } \\
\text { client/customer }\end{array}$ & 63 & 48 \\
\hline Negotiate with supplier/contractor & 48 & 52 \\
\hline Negotiate with employees & 56 & 48 \\
\hline Negotiate with T.U. representatives & 26 & 29 \\
\hline $\begin{array}{l}\text { Negotiate with public authorities (not } \\
\text { as customers) }\end{array}$ & 4 & 24 \\
\hline Negotiate with senior management & 67 & 71 \\
\hline Statistics & 26 & 24 \\
\hline Operational research & 15 & 10 \\
\hline Systems analysis & 15 & 19 \\
\hline Organisation and Methods $(\mathrm{O} \& \mathrm{M})$ & 22 & 19 \\
\hline Work study (methods study) & 15 & 14 \\
\hline Data processing & 15 & 24 \\
\hline Make formal presentations & 93 & 91 \\
\hline Plan and chair formal meetings & 82 & 76 \\
\hline Plan personnel requirements & 67 & 81 \\
\hline Recruit and select personnel & 67 & 62 \\
\hline Motivate others & 89 & 76 \\
\hline Supervise others & $8 \overline{5}$ & 91 \\
\hline Appraise personnel & 74 & 71 \\
\hline Employee training - manual workers & 22 & 19 \\
\hline Employee training - supervisors & 30 & 33 \\
\hline Employee training - management & 30 & 29 \\
\hline
\end{tabular}

Note that only the data from the Chartered members is used in the other tables in this report. 


\section{APPENDIX G}

COMPARISON OF DATA RECEIVED BY POSTAL AND BY EMAIL QUESTIONNAIRES FROM MEMBERS OF THE INSTITUTION OF ELECTRICAL ENGINEERS

The purpose of the appendix is to compare the responses on managerial skills and expertise used in their present jobs obtained by postal and by email to the sample of members of the Institution of Electrical Engineers. First we compare some of the general data from them.

\begin{tabular}{|c|c|c|}
\hline Age & $\begin{array}{c}\text { IEE members } \\
\text { sampled by } \\
\text { post } \\
\%\end{array}$ & $\begin{array}{c}\text { IEE members } \\
\text { sampled by } \\
\text { email } \\
\%\end{array}$ \\
\hline Under 30 & 0 & 0 \\
\hline $30-39$ & 20 & 39 \\
\hline $40-49$ & 32 & 28 \\
\hline $50-59$ & 37 & 33 \\
\hline $60+$ & 12 & 0 \\
\hline
\end{tabular}
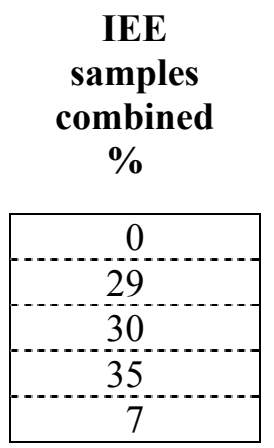

* excluding those known to be retired
Whole IEE

Corporate membership* $\%$

\begin{tabular}{|c|}
\hline 0.5 \\
\hline 22 \\
\hline 3. \\
\hline 33 \\
\hline 6 \\
\hline
\end{tabular}

IEE members

IEE members sampled by email \%

\begin{tabular}{|c|c|c|}
\hline University degree & 68 & 78 \\
\hline CNAA degree & 15 & 17 \\
\hline Diploma in Technology & & \\
\hline Professional Institution examination & 8 & 3 \\
\hline HND & & \\
\hline $\mathrm{HNC}$ & & \\
\hline NVQ & & \\
\hline Other & & \\
\hline
\end{tabular}

(The percentages are not mutually exclusive)
Hold any other higher educational
$\%$
$\%$ qualification ?

\begin{tabular}{l|l|l} 
Yes & 44 & 36 \\
\hline
\end{tabular}

Type of other higher educational

$\%$
qualifications

\begin{tabular}{|l|c|c|}
\hline MBA & 5 & 3 \\
\hline Other Management & 2 & 3 \\
\hline Teaching qualification & 7 & 14 \\
\hline $\begin{array}{l}\text { Masters degree in Engineering / } \\
\text { Technology }\end{array}$ & \\
\hline $\begin{array}{l}\text { Postgraduate Diploma / Certificate in } \\
\text { Engineering / Technology / Applied } \\
\text { Science }\end{array}$ & 7 & \\
\hline PhD, DSc & 7 & \\
\hline
\end{tabular}




\begin{tabular}{|c|c|c|c|}
\hline $\begin{array}{l}\text { Technological vs. managerial content } \\
\text { of job }\end{array}$ & $\begin{array}{c}\text { IEE members } \\
\text { sampled by } \\
\text { post } \\
\%\end{array}$ & $\begin{array}{c}\text { IEE members } \\
\text { sampled by } \\
\text { email } \\
\%\end{array}$ & $\begin{array}{c}\text { IEE } \\
\text { samples } \\
\text { combined } \\
\%\end{array}$ \\
\hline Predominantly technological & 27 & 36 & 31 \\
\hline Predominantly managerial & 42 & 28 & 35 \\
\hline Both equally & 29 & 33 & 31 \\
\hline
\end{tabular}

Level of responsibility
\begin{tabular}{|l|c|c|c|}
\hline Director / Partner & 29 & 6 & 18 \\
\hline $\begin{array}{l}\text { Manager / Chief Engineer /Chief } \\
\text { Technologist / Principal Engineer / } \\
\text { Principal Technologist }\end{array}$ & 39 & 53 & 46 \\
\hline Senior Engineer / Senior Technologist & & & \\
\hline $\begin{array}{l}\text { Professional Engineer / Professional } \\
\text { Technologist }\end{array}$ & 7 & 31 & 25 \\
\hline Other & 5 & 8 & 8 \\
\hline
\end{tabular}

\begin{tabular}{l}
$\begin{array}{l}\text { Most difficult or demanding aspect of } \\
\text { job }\end{array}$ \\
\hline People management \\
\hline Communications
\end{tabular}


Table G1

\begin{tabular}{|c|c|c|}
\hline $\begin{array}{l}\text { SKILLS AND EXPERTISE } \\
\text { REQUIRED IN PRESENT JOB }\end{array}$ & $\begin{array}{c}\text { IEE members } \\
\text { sampled by post } \\
\%\end{array}$ & $\begin{array}{c}\text { IEE members } \\
\text { sampled by } \\
\text { email } \\
\%\end{array}$ \\
\hline Costing, estimating & 88 & $81 \ldots$ \\
\hline Project financing & 76 & 50 \\
\hline Evaluate projects & 85 & 83 \\
\hline Analyse project risks & 78 & 89 \\
\hline Analyse corporate risks & 54 & 56 \\
\hline Plan and control budgets & 76 & 69 \\
\hline Company accounting & 42 & 28 \\
\hline Corporate (business) strategy & 61 & 42 \\
\hline Plan and schedule project & 88 & 89 \\
\hline Plan new product & 49 & 89 \\
\hline Patenting & 24 & 22 \\
\hline Plan research & 24 & 25 \\
\hline Plan design and development & 49 & 61 \\
\hline Plan construction & 34 & 42 \\
\hline Plan production & 22 & 22 \\
\hline Plan maintenance & 34 & 28 \\
\hline Plan stocks and materials distribution & 20 & 11 \\
\hline Plan services & 22 & 36 \\
\hline Marketing of products & 34 & 28 \\
\hline $\begin{array}{l}\text { Marketing of consultancy, technical } \\
\text { services }\end{array}$ & 24 & 31 \\
\hline Use of company law & 44 & 42 \\
\hline Use of health \& safety law & 73 & 64 \\
\hline Use of employment law & 49 & 36 \\
\hline Use of consumer safety law & 34 & 11 \\
\hline Draft contracts & 44 & 36 \\
\hline Negotiate contracts with client/customer & 63 & 44 \\
\hline Negotiate with supplier/contractor & 59 & 61 \\
\hline Negotiate with employees & 44 & 36 \\
\hline Negotiate with T.U. representatives & 15 & 11 \\
\hline $\begin{array}{l}\text { Negotiate with public authorities (not as } \\
\text { customers) }\end{array}$ & 20 & 17 \\
\hline Negotiate with senior management & 71 & 50 \\
\hline Statistics & 42 & 28 \\
\hline Operational research & 17 & 6 \\
\hline Systems analysis & 37 & 31 \\
\hline Organisation and Methods $(\mathrm{O} \& \mathrm{M})$ & 24 & 14 \\
\hline Work study (methods study) & 15 & 6 \\
\hline Data processing & 37 & 28 \\
\hline Make formal presentations & $85^{-}$ & 83 \\
\hline Plan and chair formal meetings & 85 & 81 \\
\hline Plan personnel requirements & 59 & 64 \\
\hline Recruit and select personnel & 68 & 58 \\
\hline Motivate others & 88 & 86 \\
\hline Supervise others & 85 & 83 \\
\hline Appraise personnel & 71 & 56 \\
\hline Employee training - manual workers & 20 & 19 \\
\hline Employee training - supervisors & 22 & 19 \\
\hline Employee training - management & 42 & 17 \\
\hline
\end{tabular}

Note that the data obtained by post and by email is combined in the other tables in this report. 


\section{APPENDIX H}

\section{AUTHORITY AND AUTONOMY IN PRESENT JOBS}

\section{Autonomy}

The respondents' answers to the multiple Q.6 about their authority and responsibilities for supervision can be compared with the answers to the question "Which of the following best describes the extent of your present authority ?" in this table in the 2001 Engineering Council (UK) Survey of Registered Engineers:

\begin{tabular}{|c|c|c|c|}
\hline \multicolumn{4}{|c|}{ Which of the following best describes the extent of your present authority? } \\
\hline & $\begin{array}{l}\text { Chartered } \\
\text { Engineer }\end{array}$ & $\begin{array}{l}\text { Incorporated } \\
\text { Engineer }\end{array}$ & $\begin{array}{l}\text { Engineering } \\
\text { Technician }\end{array}$ \\
\hline $\begin{array}{l}\text { I have overall responsibility for a substantial } \\
\text { organisation including policy making }\end{array}$ & $14.6 \%$ & $10.5 \%$ & $11.1 \%$ \\
\hline I have full control over senior staff & $8.5 \%$ & $5.8 \%$ & $3.5 \%$ \\
\hline $\begin{array}{l}\text { I supervise leaders of more than one group of } \\
\text { qualified staff and others }\end{array}$ & $19.5 \%$ & $16.9 \%$ & $12.9 \%$ \\
\hline I supervise a group of qualified staff & $274 . \%$ & $28.1 \%$ & $27.0 \%$ \\
\hline $\begin{array}{l}\text { Thave no managerial responsibilities, but may be } \\
\text { assigned one or more assistants }\end{array}$ & $19.3 \%$ & $24.3 \%$ & $24.2 \%$ \\
\hline $\begin{array}{l}\text { I have no authority, but may give guidance to } \\
\text { others }\end{array}$ & $10.5 \%$ & $14.2 \%$ & $20.9 \%$ \\
\hline I am under full-time training & $0.2 \%$ & $0.2 \%$ & $0.4 \%$ \\
\hline
\end{tabular}

2001 Engineering Council (UK) Survey of Registered Engineers Reproduced by permission of the Engineering Council (UK).

\section{Autonomy}

The respondents' answers about their autonomy can be compared with the answers to the question "Which of the following best describes the extent your work is supervised ?" in this table in the 2001 Engineering Council (UK) Survey of Registered Engineers:

\begin{tabular}{|c|c|c|c|}
\hline \multicolumn{4}{|c|}{ Which of the following best describes the extent to which your work is supervised ? } \\
\hline & $\begin{array}{l}\text { Chartered } \\
\text { Engineer }\end{array}$ & $\begin{array}{l}\text { Incorporated } \\
\text { Engineer }\end{array}$ & $\begin{array}{l}\text { Engineering } \\
\text { Technician }\end{array}$ \\
\hline $\begin{array}{l}\text { My work is unsupervised other than complying } \\
\text { with policy }\end{array}$ & $48.8 \%$ & $47.9 \%$ & $54.2 \%$ \\
\hline My work is occasionally reviewed in outline & $40.6 \%$ & $39.0 \%$ & $29.0 \%$ \\
\hline My work is regularly reviewed & $8.8 \%$ & $11.0 \%$ & $13.1 \%$ \\
\hline My work is frequently reviewed in detail & $1.2 \%$ & $1.4 \%$ & $1.4 \%$ \\
\hline All my work is checked in detail & $0.6 \%$ & $0.6 \%$ & $2.2 \%$ \\
\hline
\end{tabular}

2001 Engineering Council (UK) Survey of Registered Engineers

Reproduced by permission of the Engineering Council (UK). 


\section{APPENDIX I}

RESEARCH STAFF

\section{A DUDMAN}

1990 to date: Computer Services, Manchester School of Management, University of Manchester Institute of Science \& Technology, and part-time consultant, employed on data input and analysis, creating web pages, design of Internet sites and data research projects for city authorities, police and RAF.

\section{S H WEARNE}

1984 to date: Visiting Senior Research Fellow, Project Management Division, University of Manchester Institute of Science \& Technology. Originally engineering apprentice and 'Sandwich' course student followed by postgraduate training in hydro-power engineering. Employed in design, planning, construction and co-ordination of water power schemes in Spain, UK and South America and then construction, design and project management of nuclear power contracts in UK and Japan. Senior Lecturer, Leader of Project Management Group, University of Manchester Institute of Science $\&$ Technology and then Professor of Technological Management, University of Bradford (Professor Emeritus).

Committees: Council of Engineering Institutions 'The Engineer in Society' syllabus panel. Engineering Management Board, Institution of Mechanical Engineers. Syllabus Sub-Committee, Diploma in Engineering Management. Engineering Management Committee, Institution of Civil Engineers. Continuing Professional Development panel, Institution of Chemical Engineers. Planning group, European Institute for Advanced Project and Contract Management. 


\section{THE CENTRE FOR RESEARCH IN THE MANAGEMENT OF PROJECTS}

Pariser Building

University of Manchester Institute of Science \& Technology

P O Box 88, Manchester M60 1QD, UK

Tel: + 44 (0) $1612004590 \quad$ Fax: + 44 (0) 1612008969

Email: crmp@umist.ac.uk 



\section{Professional Engineers' Needs for \\ Managerial Skills and Expertise}

\section{SUMMARY OF CONCLUSIONS}

The information obtained from the samples of Chartered Engineers leads to the following general conclusions:

- Most engineers' careers demand a variety of 'managerial' skills and expertise, particularly in two groups of topics: leadership, and the management of projects.

- These demands vary with age and level of responsibility. Some management skills and knowledge are required early in engineers' careers. As might be expected, some are needed later.

- Some topics classically included in 'management' courses are little used by most engineers, for example work study and operational research.

- There are some differences in the needs between the members of different Institutions, but all are similar in most requiring skills and expertise in leadership and the management of projects.

- Compared with a similar survey in 1979, managerial skills and expertise have become relatively more important in engineers' jobs, particularly in costing, accounting, new product planning, marketing, negotiating and law.

- The engineers questioned in the survey need and want more preparation for their current and future managerial tasks.

Many of the results are no surprise. They confirm earlier surveys or accord with common sense. They indicate that valid information was obtained.

The time available limited the size of the sample to 1 in 300 of Chartered Engineers. Not all the results are therefore conclusive and several questions require further investigation.

This report replaces an interim report issued in October 2002. 


\section{ACKNOWLEDGEMENTS}

Our great thanks are due to the engineers who sent back completed questionnaires. The willingness of so many to do so was vital. We are also grateful to the individuals and organizations who gave advice and comments on the design of the questionnaire and on the analysis of the results.

\section{SUPPORT}

Running the survey in 2002 was proposed by the EMTA, an educational and training charity owned by the engineering industry. EMTA met the costs of printing the questionnaires, the survey coordinator's expenses, data processing, production of data CD's and printing the reports.

Other costs of this survey were shared thus:

The Engineering Council (UK): Staff time for advice and data analysis.

The Institutions: Posting the questionnaire to samples of their members, providing reply envelopes and returning the answered questionnaires for data processing.

UMIST Centre for Research in the Management of Projects: Staff time for planning and coordinating the survey, data processing and drafting the reports. 


\section{CONTENTS OF THE REPORT}

Objective

Scope of the 2002 Survey

Scope of the Questionnaire

Scale of the Response

Data Obtained

Validity of the Data Obtained

Comments

Conclusions

References and Bibliography p. 1

2

3

4

5

19

20

34

35

\section{APPENDICES}

A. Specimen questionnaire.

B. Answers to the question what is the most difficult aspect of the respondent's job.

C. Scaling of answers to questions on range of jobs of people responsible to, etc.

D. Answers to the question about support expected from Institutions in achieving managerial ambitions.

E. Answers to invitation for respondents' general comments.

F. Comparison of data from Chartered and non-Chartered members of the Institution of Mechanical Engineers.

G. Comparison of data obtained by postal and by email questionnaire to members of the Institution of Electrical Engineers.

H. Engineering Council (UK) data on engineers' authority and supervision.

I. Research staff. 


\section{DEFINITIONS}

In this report the word engineer is used as recognised in the U.K. by membership of a chartered institution.

The word Institution is used to mean a chartered engineering institution.

The word management is used to mean the process of effecting some purpose and managing business. For this survey 47 topics are listed as constituting the elements of management.

\section{COPIES}

Copies of all or parts of this report may be freely made, provided that full acknowledgement is made to the source. 